\title{
Depositional evolution of the Upper Carboniferous - Lower Permian Wordiekammen carbonate platform, Nordfjorden High, central Spitsbergen, Arctic Norway
}

\author{
Morten Ahlborn ${ }^{1,2} \&$ Lars Stemmerik ${ }^{3,4}$ \\ ${ }^{1}$ Department of Geosciences and Natural Resources Management, University of Copenhagen, Øster Voldgade 10, DK-1350 Copenhagen K, Denmark. \\ ${ }^{2}$ Dong Energy E\&P Norge AS, Veritasveien 25, N-4002, Stavanger, Norway. \\ ${ }^{3}$ Natural History Museum of Denmark, University of Copenhagen, Øster Voldgade 5-7, DK-1350 Copenhagen K, Denmark. \\ ${ }^{4}$ University Centre in Svalbard, P.O. Box 156, N-9171, Longyearbyen, Norway. \\ E-mail corresponding author (Morten Ahlborn): moahl@dongenergy.no
}

This paper presents the first comprehensive study of the Wordiekammen carbonate platform on the Nordfjorden High, Central Spitsbergen. The Wordiekammen succession is divided into four depositional sequences bounded by subaerial exposure surfaces and consists of 12-84 m-thick wedgeshaped sequences being thickest in the distal area and thinner on the crest of the High. The uppermost Finlayfjellet Beds (Tyrrellfjellet sequence 2) represents in contrast a uniform sequence.

The Wordiekammen Formation is composed of 11 depositional carbonate facies and three overprint facies which are grouped into 10 facies associations. Each association represents a predictable pattern of facies, $0.5-22 \mathrm{~m}$ thick, which is repeated many times producing a distinct cyclicity in the succession. The Wordiekammen Formation is composed of 50 depositional cycles, 21 cycles in the Kapitol Member and 29 cycles in the Tyrrellfjellet Member. Analysis of the well-dated Tyrrellfjellet Member indicates that the succession was controlled by mixed $100 \mathrm{kyr}$ and $400 \mathrm{kyr}$ cyclicity signals which are believed to be a reflection of eustatic sea-level fluctuation and tectonic instability. Allocyclic control on the deposition dominated the majority of the Wordiekammen succession, and an abrupt change in depositional style in the uppermost Finlayfjellet Beds is believed to reflect the break-down of the Gondwanaland ice sheets and the end of glacio-eustaic control.

Four key lithological intervals and unconformities have been correlated across the Billefjorden Fault Zone to the time-equivalent succession in Bünsow Land. Based on the correlation, it is considered that the distal part of the Nordfjorden High towards the west and the carbonate platform on Bünsow Land reflected a similar geological setting while the up-dip and crestal part of the Nordfjorden High was a positive feature that divided the two carbonate platforms during sea-level lows. Finally, it is believed that the Nordfjorden High remained a homoclinal carbonate ramp up to at least Late Asselian times.

Keywords: Wordiekammen Formation, Carbonates, Gipsdalen Group, Upper Carboniferous-Lower Permian, Nordfjorden High, Central Spitsbergen

Received 24. August 2014 / Accepted 4. May 2015 / Published online 18. September 2015

\section{Introduction}

The Wordiekammen Formation in central Spitsbergen, Arctic Norway, is a platform succession of cyclic carbonates of Moscovian-Sakmarian (Late Carboniferous-Early Permian) age. It is one in a mosaic of carbonate platforms along the northern margin of the Pangean supercontinent, from Arctic Canada in the west to the northern Timan-Pechora Basin, Arctic Russia, in the east, formed during a time interval characterised by pronounced glacio-eustatic sea-level variations (Veevers \& Powell, 1987; Crowley \& Baum, 1991). Timeequivalent carbonates are well known from the offshore areas of the Barents Shelf where they are seen as an important reservoir target (Stemmerik et al., 1994, 1995, 1999; Bugge et al., 1995; Ehrenberg et al., 1998; Worsley et al., 2001; Larssen et al., 2005; Stemmerik \& Worsley, 2005; Stemmerik, 2008).

Ahlborn, M. \& Stemmerik, L. 2015: Depositional evolution of the Upper Carboniferous - Lower Permian Wordiekammen carbonate platform, Nordfjorden High, central Spitsbergen, Arctic Norway. Norwegian Journal of Geology 95, 91-126. http://dx.doi.org/10.17850/njg95-1-03.

() Copyright the authors.

This work is licensed under a Creative Commons Attribution 4.0 International License. 
The Wordiekammen carbonate platform in Spitsbergen forms the post-rift succession to a significant Mid Carboniferous rift event and older Carboniferous lineaments seem to have influenced deposition also in Wordiekammen time. The most important is the N-Soriented Billefjorden Fault Zone which separates the Nordfjorden High from the better studied areas to the east (Holliday \& Cutbill, 1972; Lønøy, 1995; Pickard et al., 1996; Samuelsberg \& Pickard, 1999; Samuelsberg et al., 2000; Eliassen \& Talbot, 2003; Blomeier et al., 2008 2011)).

This paper presents the first comprehensive study of the Wordiekammen carbonates on the Nordfjorden High. The purpose is to describe facies, facies associations and cyclicity to unravel the depositional evolution of the Late Palaeozoic carbonate ramp. It is based on detailed analysis of 13 sedimentary sections. The succession is characterised by metre-scale, exposure-capped cycles which can be traced for long distances. They stack into four lower-order sequences, $12-84 \mathrm{~m}$ thick, of which the uppermost two can be correlated eastward across the Billefjorden Fault Zone to the time-equivalent succession in Bünsow Land on the Ny Friesland High as described by Samuelsberg \& Pickard (1999).

\section{Geological setting}

During Late Palaeozoic times, the Barents Shelf consisted of interlinked intercratonic basins that formed part of a mosaic of sedimentary basins located on the northern margin of Pangea (Stemmerik \& Worsley, 1989; Gabrielsen et al., 1990; Gudlaugsson et al., 1998; Gernigon \& Brönner, 2012). Extension started during the Early Carboniferous and created several NNWSSE-oriented half-grabens in the western Barents Shelf (Steel \& Worsley, 1984). In central Spitsbergen, Bashkirian faulting along the N-S-oriented Billefjorden Fault Zone resulted in two westward-tilted half-grabens, the Nordfjorden High to the west and the Ny Friesland High to the east (Fig. 1). The western depositional centres, the Billefjorden Trough on the Ny Friesland High and the St. Jonsfjorden Basin on the Nordfjorden High, are characterised by thick, Mid Carboniferous synrift successions of the Ebbadalen and Minkinfjellet Formations and their equivalents, resting on Lower Carboniferous Billefjorden Group siliciclastics of the earliest synrift period (Steel \& Worsley, 1984; Johannesen \& Steel, 1992; Dallmann, 1999). In contrast, the more slowly subsiding crestal areas, the Nordfjorden and $\mathrm{Ny}$

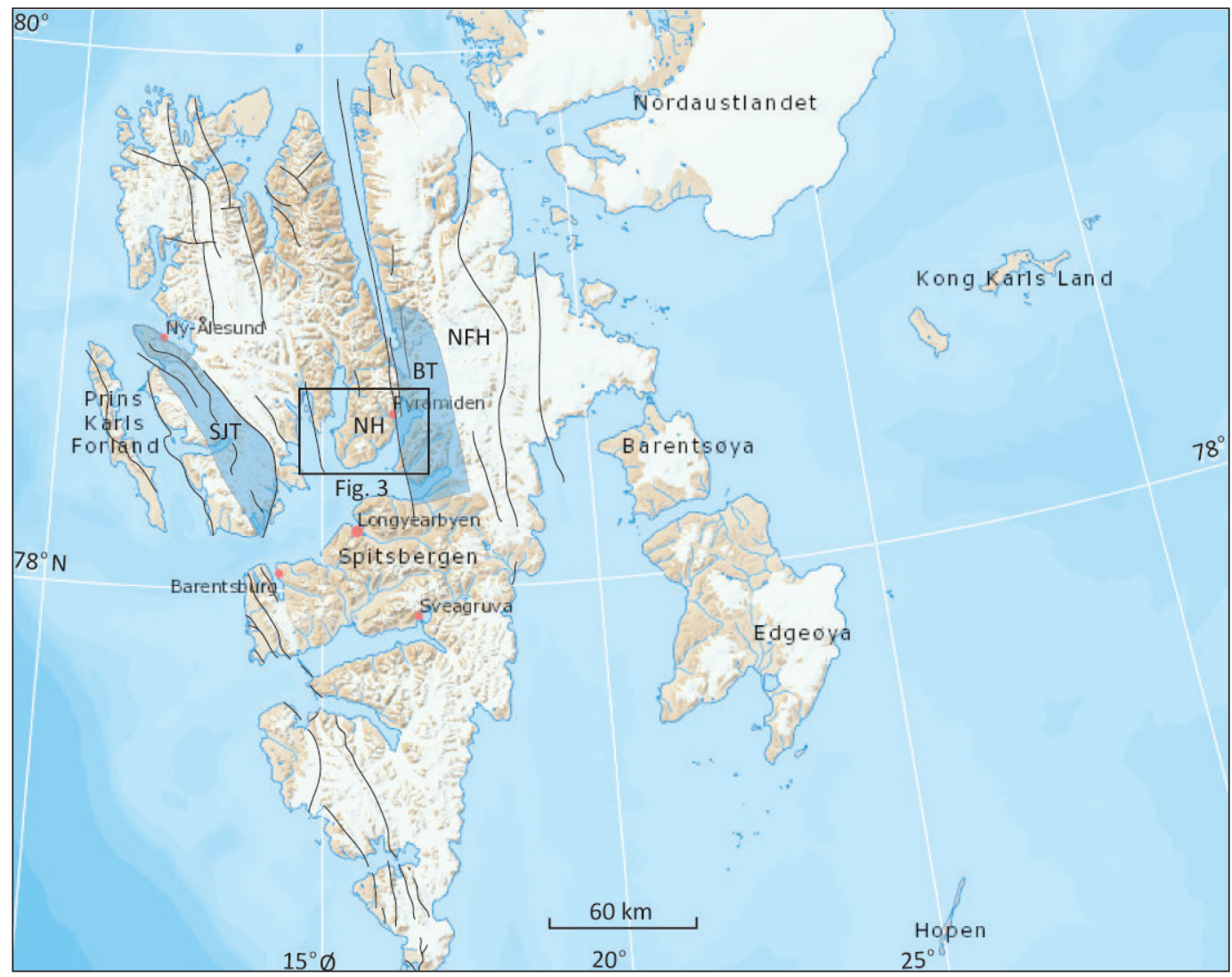

Figure 1. Overview map of Svalbard showing major structural elements. Abbreviations: NH - Nordfjorden High, BT - Billefjorden Trough, NFH Ny Friesland High, SJT - St. Jonsfjorden Trough. The box defines the outline of Fig. 3. The figure is constructed from a map from http://toposvalbard. npolar.no/ while the structural elements are modified from Dallmann (1999). 
Friesland highs, were not transgressed until later in the Carboniferous and here the Wordiekammen platform carbonates rest unconformably on Devonian red bed siliciclastics and older rocks in most areas (Dallmann et al., 1999).

The Wordiekammen Formation is separated from the overlying Lower Permian Gipshuken Formation by a subaerial exposure surface with microkarstic relief in central Spitsbergen (Stemmerik \& Worsley, 2005). Deposition of the Gipshuken carbonates and evaporites was followed by a prolonged break in sedimentation caused by tectonically controlled uplift of the Barents Shelf margins and increased subsidence of basin centres in the offshore areas (Stemmerik \& Worsley, 2005).

\section{Nordfjorden High}

The studied part of the Nordfjorden High forms the eastern up-dip areas of the Nordfjorden High area (Figs. 2, 3). It is bounded to the east by the Billefjorden Fault Zone and to the west by the St. Jonsfjorden Basin (Harland \& Geddes, 1997). It forms the N-Selongated, $40 \mathrm{~km}$-wide crestal area of the westward tilted Nordfjorden High where Wordiekammen carbonates unconformably overlie Devonian sediments (Fig. 4) or in isolated outliers of Lower Carboniferous Billefjorden siliciclastics (Steel \& Worsley, 1984; Johannesen \& Steel, 1992).

During Bashkrian rifting, the High acted as a source area for the syntectonic Ebbadalen and Minkinfjellet formation siliciclastics in the Billefjorden Trough to the east (Steel \& Worsley, 1984; Johannesen \& Steel, 1992; Eliassen \& Talbot, 2003). Transgression of the High occurred during the Moscovian (Nilsson, 1988) and laterally extensive carbonate platforms of the Wordiekammen Formation were established as the siliciclasic source areas drowned (Steel \& Worsley, 1984).

\section{Lithostratigraphic framework of the Nordfjorden High}

The Gipsdalen Group includes the Wordiekammen and the Gipshuken formations on the Nordfjorden High. The Wordiekammen Formation is dated to be Moscovian to Early Sakmarian in age based on fusulinids (Nilsson, 1993; Nilsson \& Davydov, 1997; Davydov \& Nilsson, 1998). It is divided into the Kapitol and Tyrrellfjellet members and two prominent units, the Brucebyen and Finlayfjellet Beds, are also distinguished (Dallmann, 1999) (Fig. 2).

The boundary between the Kapitol and Tyrrellfjellet members was originally placed at the base of a thin conglomerate/sandstone interval approximately $10 \mathrm{~m}$ below the Fusulina Limestone (Brucebyen Beds) (Cutbill \& Challinor, 1965). However, in his review of the Upper Palaeozoic lithostratigraphy of Svalbard, Dallmann (1999) redefined the boundary to a somewhat higher level at the base of the Brucebyen Beds. This definition is in accordance with Samuelsberg \& Pickard (1999) and supported by the easy recognition of the fusulinid-rich Brucebyen Beds. However, based on this definition the Kapitol Member includes a major hiatus in the most proximal areas along Billefjorden

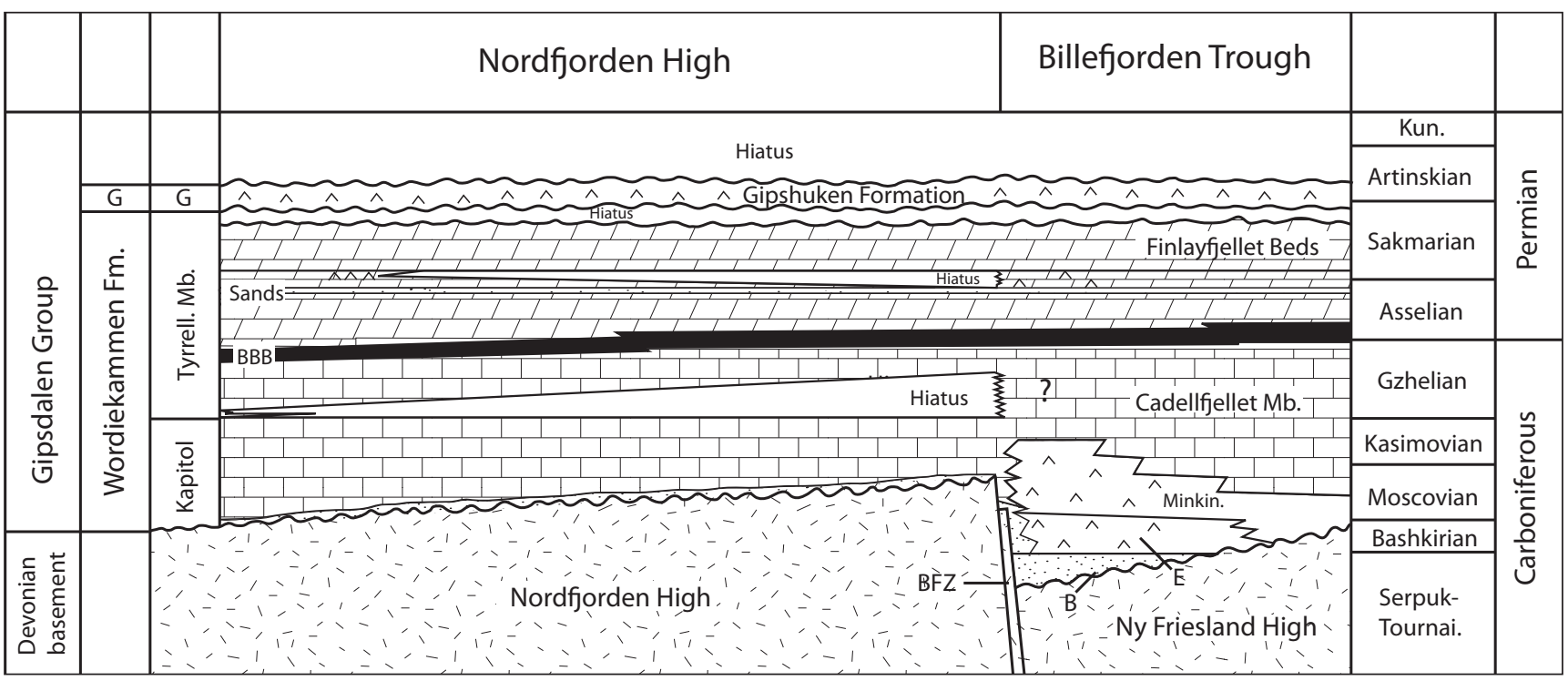

Figure 2. Stratigraphic outline of the Late Palaeozoic strata of central Spitsbergen. The stratigraphy of the Billefjorden Trough is modified from Cutbill \& Challinor (1965), (Dallmann (1993), Lønøy (1995) and Pickard et al. (1996). Abbreviations: BFZ - Billefjorden Fault Zone, B Billefjorden Group, E - Ebbadalen Formation, G - Gipshuken Formation, Minkin. - Minkinfjellet Formation, BBB - Brucebyen Beds. 


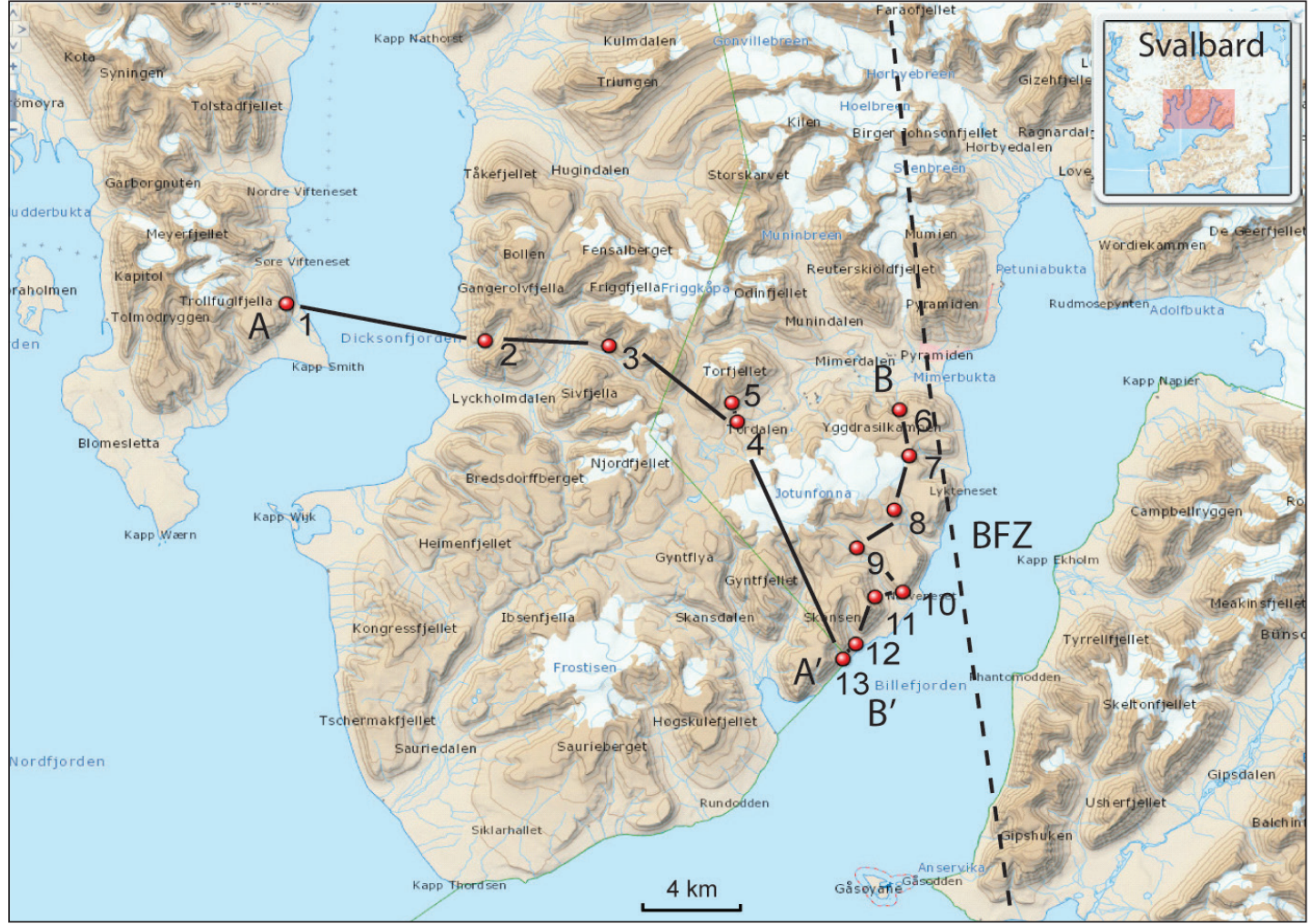

Figure 3. Locations of the studied sections on the Nordfjorden High. (1) Trollfuglfjella, (2) Gangerrolvfjella, (3) Rinddalen, (4) Torelva, (5) Torfjella, (6) Yggdrasilkampen North, (7) Yggdrasilkampen South, (8) Nidedalen, (9) Alvrekdalen West, (10) Alvrekdalen North, (11) Alvrekdalen South, (12) Asvindalen, (13) Skansen. Abbreviation: BFZ - Billefjorden Fault Zone.

(localities 6-13 in Fig. 3) and the boundary is highly diachronous being oldest in the more distal sections to the west (Nilsson, 1993).

In this paper we refer to the Kapitol and Tyrrellfjellet members as they were originally defined and used by Cutbill \& Challinor (1965).

Kapitol Member - sensu Cutbill \& Challinor (1965) (Early Moscovian -Early Gzhelian)

The Kapitol Member represents the lower part of the Wordiekammen Formation and rests uncomformably on tilted Devonian or locally Lower Carboniferous sedimentary rocks (Fig. 4). The top is here placed at the base of a thin sandstone or conglomerate interval in the proximal sections and at the base of a major composite Microcodium horizon in the more distal parts of the area (see Fig. 5A-D). The Kapitol Member is 36-78 m thick, thinnest in the most proximal areas along Billefjorden and thickest in the west. It is characterised by metre-scale carbonate cycles capped by subaerial exposure surfaces defined by Microcodium networks, caliche and more rarely karst. The most complete sections consist of up to 21 cycles (see Fig. 5A, B). The member is divided into two sequences, Kapitol sequence 1 and Kapitol sequence 2 , by a prominent karst surface which can be traced from the most proximal sections along Billefjorden and down- dip as far as Torelva in western central Dickson Land (Fig. 5A, B).

The upper boundary is marked by an up to $3.5 \mathrm{~m}$-thick sandstone interval in the crestal areas and a thinner sandstone at Trollfuglfjella; elsewhere in the down-dip areas it is characterised by a thick and dense Microcodium interval (see Fig. 5A, B). The sandstone is considered to be laterally equivalent to the Gerritfjellet Beds in the Billefjorden Trough (Samuelsberg \& Pickard, 1999).

Tyrrellfiellet Member - sensu Cutbill \& Challinor (1965) (Early Gzhelian - Early Sakmarian)

The Tyrrellfjellet Member (Fig. 6) represents the upper part of the Wordiekammen Formation. It is up to $120 \mathrm{~m}$ thick and consists of a lower interval of cyclic carbonates with three distinctive, laterally widespread sandstone intervals and an upper interval of biogenic, crinoidrich carbonates which lack the distinctive cyclicity so characteristic for the lower part of the formation. This upper interval corresponds to the Finlayfjellet Beds. It is separated from the underlying sediments by a karst surface in the proximal areas along Billefjorden and rests on a succession of peritidal sediments further down-dip.

The Brucebyen Beds are recognised as a distinctive 1-4 $\mathrm{m}$-thick unit of fusulinid wackestone and packstones 


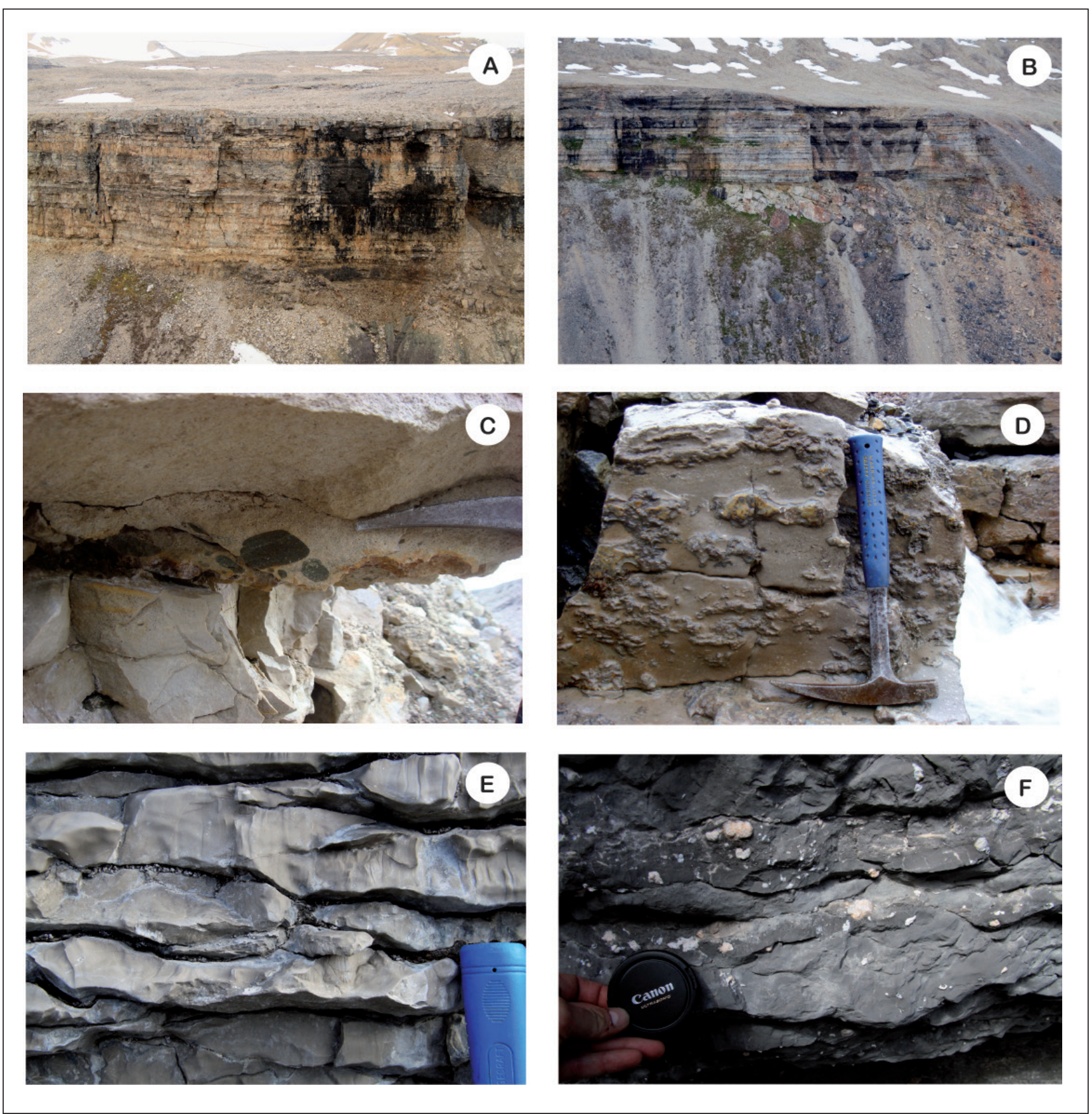

Figure 4. Photographs of the Kapitol Member. (A) The exposed Kapitol succession of Torfjella. (B) The onlap of the Kapitol Member on top of tilted Devonian red-bed deposits. A well exposed angular unconformity observed from Torfjella. (C) Basal conglomerate of the Kapitol Member, Asvindalen. The rounded clast represents reworked Devonian red-bed deposits. (D) Typical cherty mudstones to wackestones of the Kapitol Member. (E) Black Crag mudstones exposed at Yggdrasilkampen N. (F) Black Crag with small evaporite nodules, Yggdrasilkampen N.

across the High (Fig. 6). Fusulinid data indicate that the bed is highly diachronous and spans the Daixina sokensis (F) and Schwagerina robusta $(\mathrm{G})$ fusulinid zones of Nilsson (1993).

The Tyrrellfjellet Member consists of up to 29 exposure capped cycles and the sediments have been grouped into two more or less tabular sequences, respectively around 85 and $45 \mathrm{~m}$ thick (see Fig. 5C, D).

\section{Methods}

This study is based on detailed analysis of 13 vertical sections along a $25 \mathrm{~km}$-long, E-W cross section of the Nordfjorden High from Trollfuglfjella down-dip to the west to a number of crestal sections along Billefjorden to the east (see Fig. 5A-D). The Billefjorden sections form an $11 \mathrm{~km}$-long strike-section of the crestal area. The sections give a pseudo 3-dimentional coverage of the 


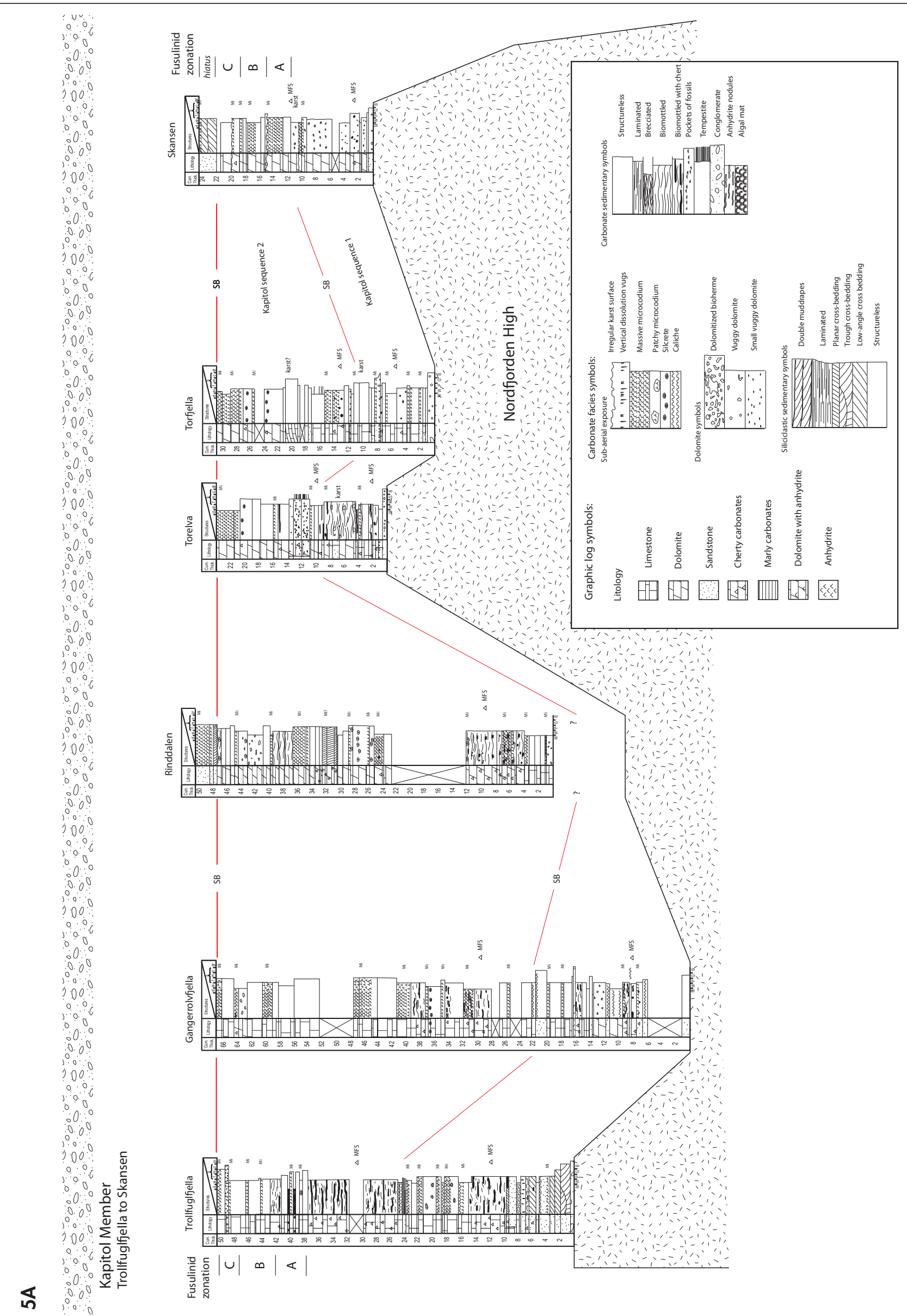


is

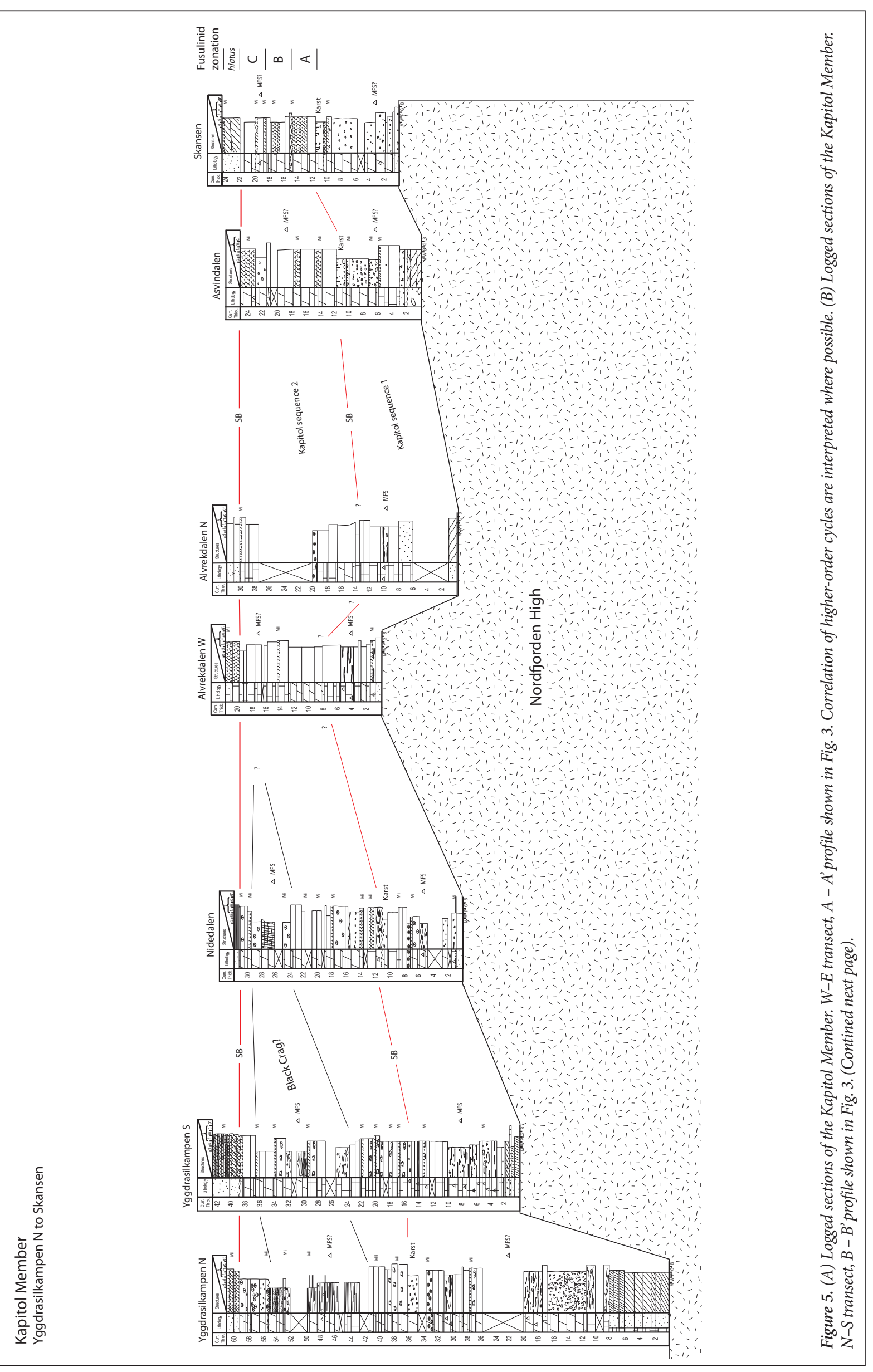




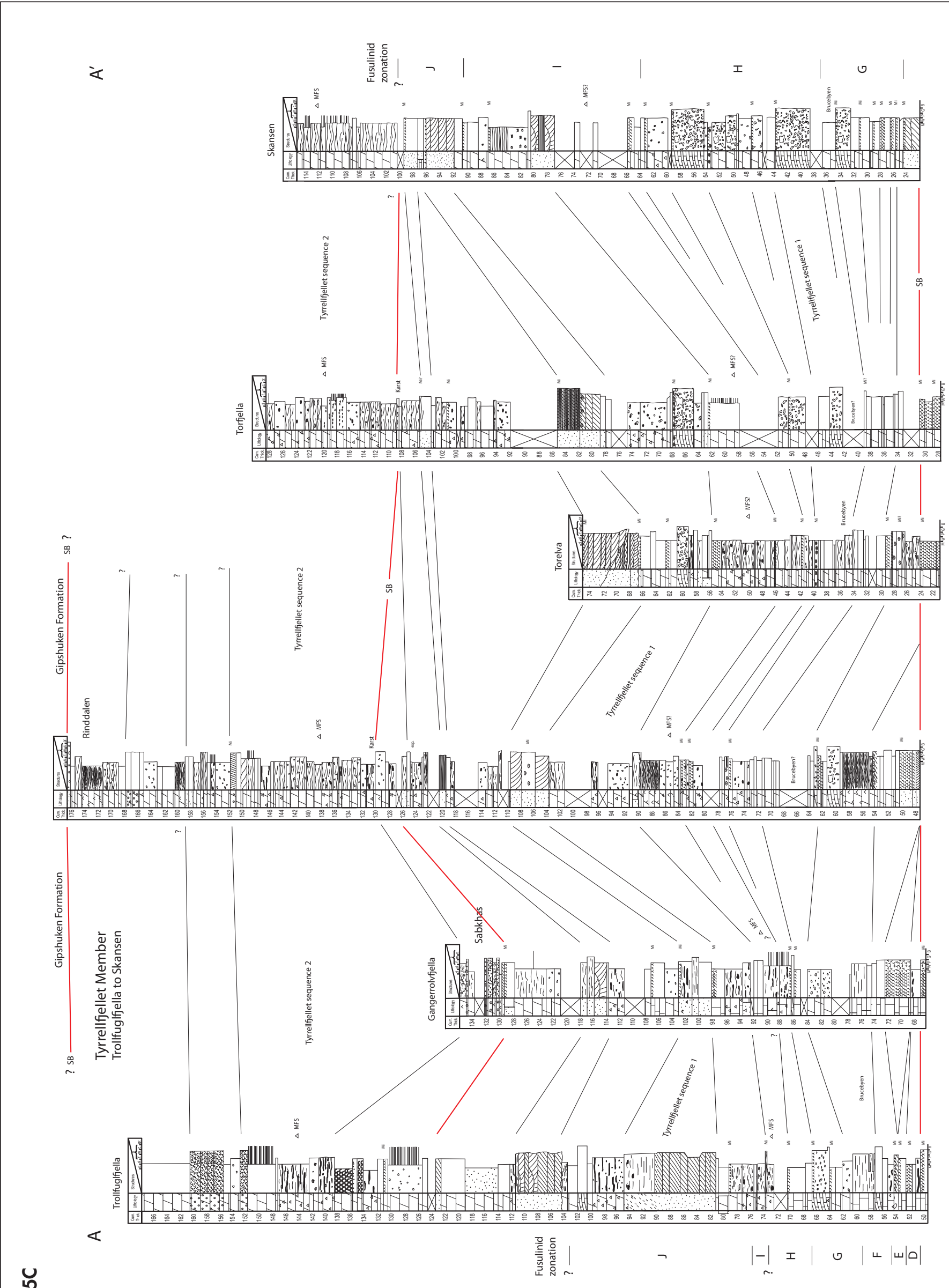




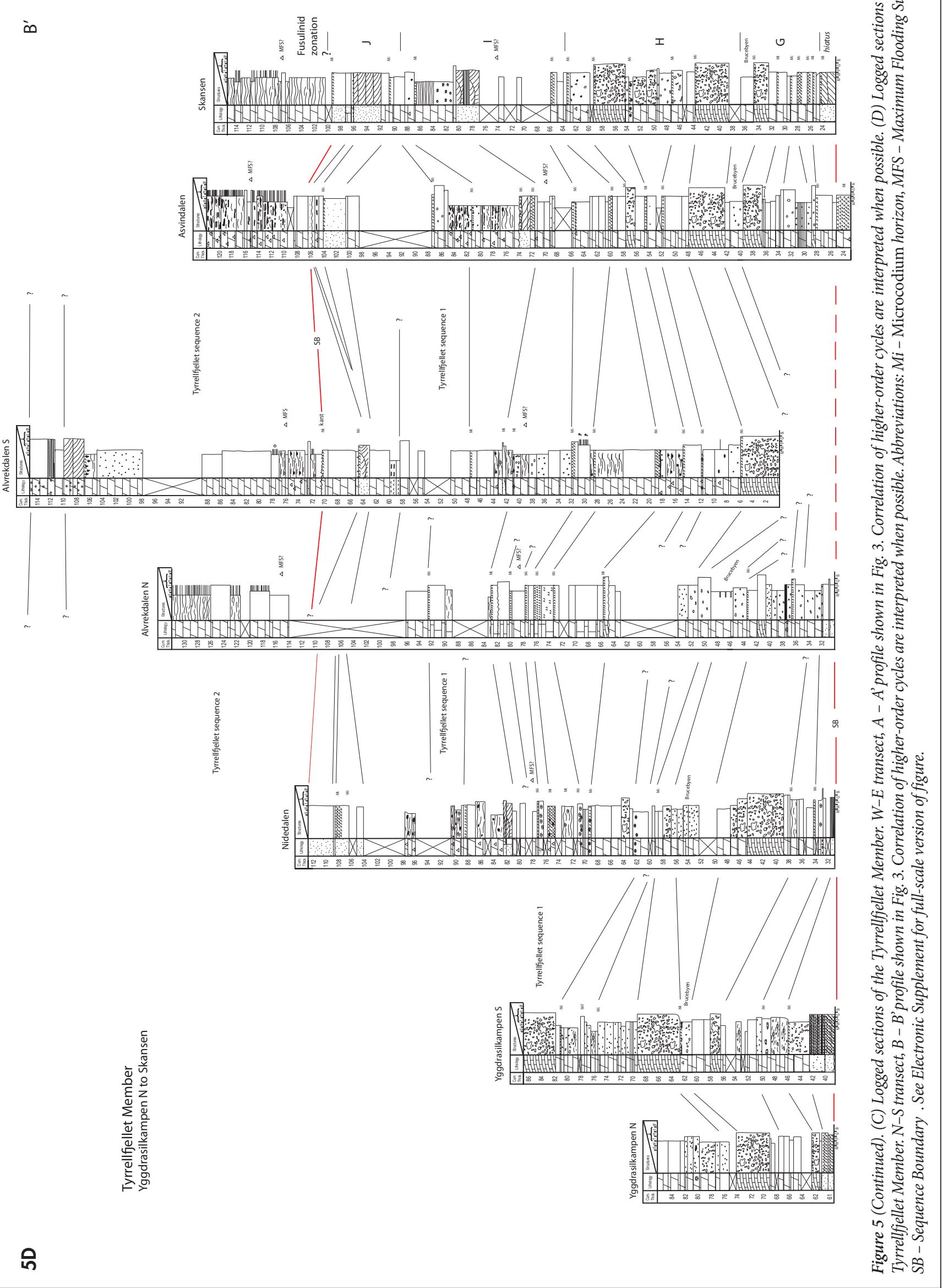




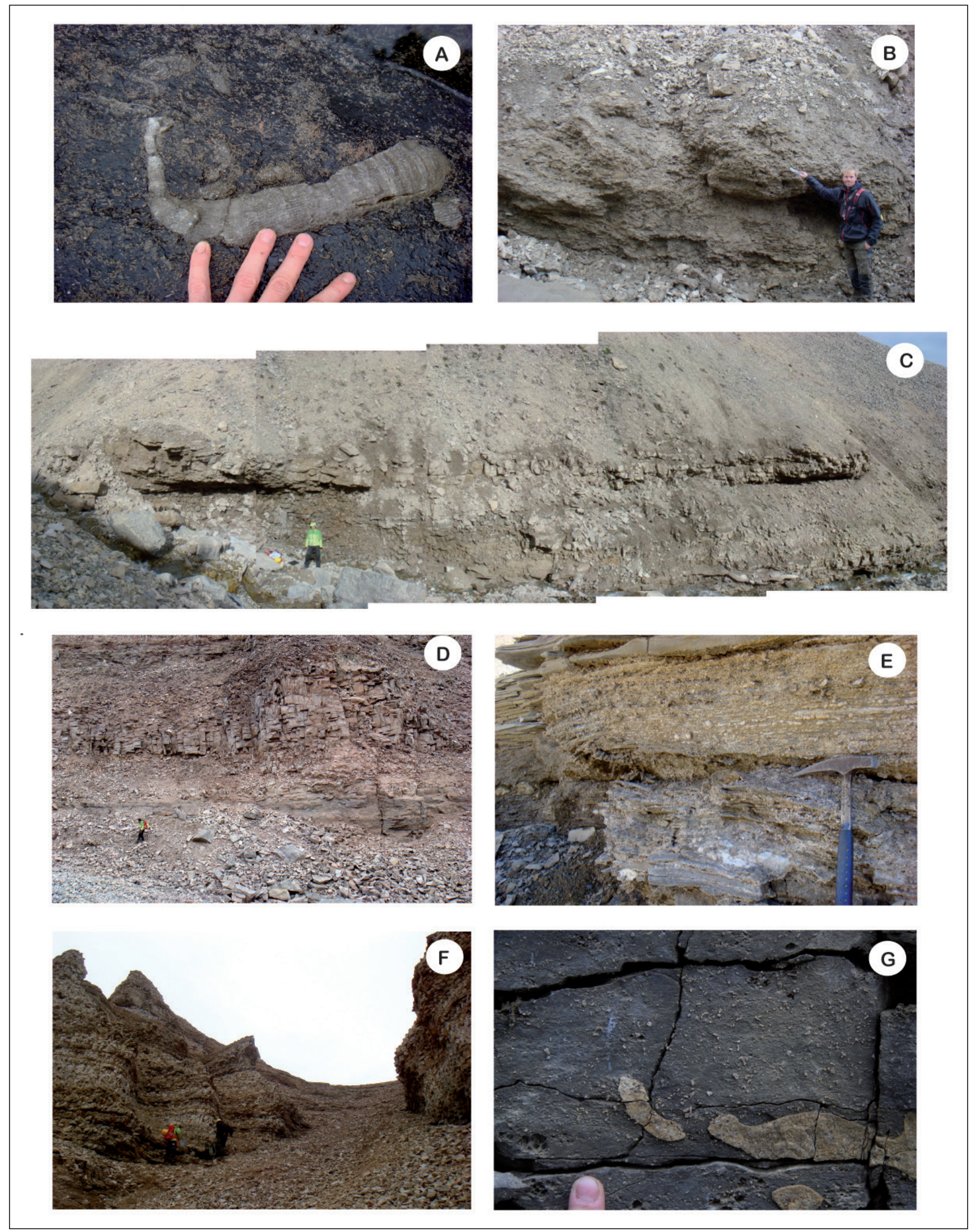

Figure 6. Photographs of the Tyrrellfjellet Member. (A) The Brucebyen Beds with a large solitary coral, Trollfuglfjella. (B) Brecciated Paleoaplysina bindstones, Paleoaplysina bioherm 2, Asvindalen. (C) Composite photograph of the Paleoaplysina bioherm 1, Asvindalen. (D) The cliff-forming sandstone 2 interval, Trollfuglfjella. (E) Sabkha facies, Gangerrolvfjella. (F) Dolomitised Finlayfjellet Beds, Tyrrellfjellet sequence 4, Trollfuglfjella. (G) Bryozoan-crinoid wackestones to packstones, Finlayfjellet Beds, Asvindalen. 
Upper Carboniferous - Lower Permian outcrops of the eastern Nordfjorden High (Fig. 3).

The outcrop studies have been supplemented with detailed microfacies analysis. A total of 261 standardsized $(27 \times 46 \mathrm{~mm})$ thin-sections have been studied using semiquantitative facies analysis to better constrain the grain composition and to identify early diagenetic overprints. Eleven carbonate facies have been identified, based on combined macro- and microfacies analysis. The carbonates are classified using the modified Dunham and Embry and Klovan classification (Dunham, 1962) and the classification of porosity in the thin-sections follows Choquette \& Pray (1971).

Two of the studied sections, Trollfuglfjella and Skansen, are well dated based on fusulinids (Nilsson, 1993; Nilsson \& Davydov, 1997). The section at Trollfuglfjella is stratigraphically most complete and the $168 \mathrm{~m}$-thick carbonate succession is divided into 10 fusulinid zones spanning the Moscovian to Early Sakmarian (Nilsson, 1993). The Skansen section is stratigraphically less complete with a major hiatus spanning the Late Kasimovian to Mid Gzhelian D, E, F fusulinid zones of Nilsson (1993). Correlation from the dated sections to undated sections is based on cyclo- and sequencestratigraphic interpretations. The presence of laterally widespread sandstone units in the upper part of the succession and distinctive Microcodium and karst horizons have been particularly useful in establishing detailed correlation between the sections.

\section{Sedimentary facies}

The Wordiekammen Formation of the Nordfjorden High consists mainly of carbonates with some siliciclastics and rare evaporites. Based on field observations and microfacies analysis of thin-sections, we have recognised 11 primary depositional carbonate facies. They are named on the basis of the most common grain types or other lithological characteristics. Additionally, three characteristic types of diagenetic overprint resulting from subaerial exposure are recognised.

\section{Karst-overprinted carbonates}

Description: The karst-overprinted carbonates are characterised by an upper irregular surface composed of limestone pavement or karren while numerous vugs or small caverns of various sizes dominate the interval below (Fig. 7). The surface is marked by a colour contrast from white karst-overprinted carbonates to darker limestones filling the karst relief. A dark, dense and chaotic network of Microcodium is abundant in the uppermost part and in some areas is accompanied by vertical dissolution cracks that terminate upward at the irregular surface. Below is an interval dominated by white to yellow dolomites with numerous vugs or caverns of various size. The dissolution vugs and caverns form ellipsoidal geometries of $2-800 \mathrm{~cm}$ in length and 2-400 $\mathrm{cm}$ in height and are often organised and concentrated in horizons. This feature is characteristic for karstified carbonates in the lowermost part of the Asvindalen and Skansen sections. At other localities, the dissolution vugs are filled with laminated silt or fine-grained sand.

In thin-section, the karst-overprinted carbonates consist of displacive fine-crystalline dolomite crystals with numerous vugs. The porosity is mostly intercrystalline and vuggy, and locally saddle dolomite crystals form late cement in vugs. No fossils have been detected in thinsections although they are locally observed in outcrops.

Occurrence: Karst-overprinted carbonates are relatively uncommon and are mostly seen as thin microkarst horizons in the lower part of Kapitol sequence 1. The most pronounced karst-overprinted interval occurs at the top of the Kapitol sequence 1 in the up-dip parts of the study area. This interval becomes thinner and less distinctive down-dip at Trollfuglfjella. The top of the Tyrrellfjellet sequence 1 forms a second pronounced karst horizon across most of the carbonate ramp except in the distally located Trollfuglfjella and Gangerrolvfjella sections.

Interpretation: The two, most pronounced, karstoverprinted carbonate intervals in the upper Kapitol sequence 1 and top Tyrrellfjellet sequence 1 may either reflect longer periods of subaerial exposure of the area, exposure during more humid time intervals or a combination. The preservation of secondary porosity indicates that karst-associated cementation was minor, thus suggesting that the karst intervals represent relatively immature systems (Loucks, 1999; Purdy \& Waltham, 1999; Saller et al., 1999).

\section{Microcodium-overprinted facies}

Description: Microcodium is easily identified in outcrop as networks of brown to dark calcite crystals penetrating down from a relatively well defined surface (Fig. 8). We have identified two subfacies based on the density of Microcodium in the primary sediment. In the massive Microcodium horizons, $60-90 \%$ of the original sediment is replaced whereas in the patchy Microcodium replacement is less pronounced and occurs as networks and patches replacing $10-50 \%$ of the original sediment.

The massive Microcodium horizons are 10-300 cm thick, massive and show little lateral variation. They are often underlain by more patchy occurrences of Microcodium and are commonly associated with a characteristic horizon of chert nodules $0.5-1.5 \mathrm{~m}$ below the base. The chert nodules are up to $15 \mathrm{~cm}$ thick, often elongated and characterised by a concentric pattern of dark and light layers (Fig. 8D). 

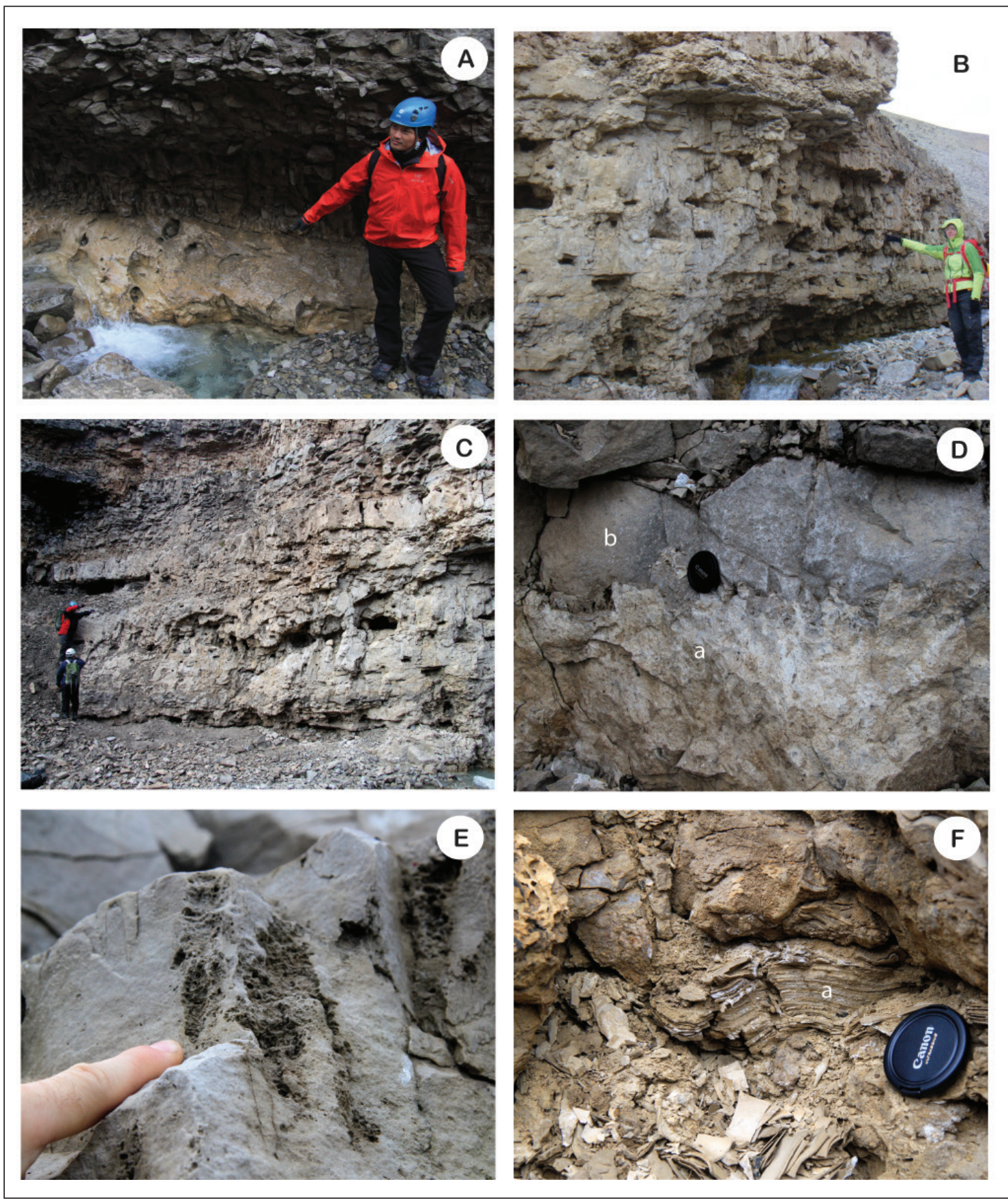

Figure 7. (A-C) Karstic overprinted interval, Top Kapitol sequence 1, Asvindalen. The characteristic horizontally aligned vugs and cavities reflect dissolution at the groundwater table. The observation of several cavity-dominated surfaces reflects various levels of groundwater during the subaerial exposure and karstification. (D) Karstic overprinted interval, Top Kapitol sequence 1, Nidedalen. (a) White karst-overprinted interval with an irregular surface, Top Kapitol sequence 1 (Nidedalen). (b) Overlying dark grey TST wackestones of the overlying depositional cycle. (E) Vertical dissolution cracks of the uppermost part of the karstic interval, Top Kapitol sequence 1, Skansen. (F) Karstic interval containing dissolution vugs and (a) cavities filled with laminated silt and fine-grained sand.

The patchy Microcodium horizons are $30-100 \mathrm{~cm}$ thick and characterised by 1-60 cm-long and 1-30 cm-thick patches of Microcodium crystals (Fig. 8). The concentration commonly increases upwards toward a more or less well-defined surface. Occasionally, this type of Microcodium replacement is also overlying concentric chert nodules.

In thin-section, Microcodium is easily recognised as accumulations of yellowish and brown calcite crystals with sweeping extinction. Diagnostic and well-preserved Microcodium with prismatic crystals radiating out from a central hollow is relatively rare.

Occurrence: The Microcodium-overprinted carbonates are abundant in most of the Wordiekammen Formation but very rare in the upper Tyrrellfjellet sequence 2 . Microcodium overprinting is recognised in all types of 

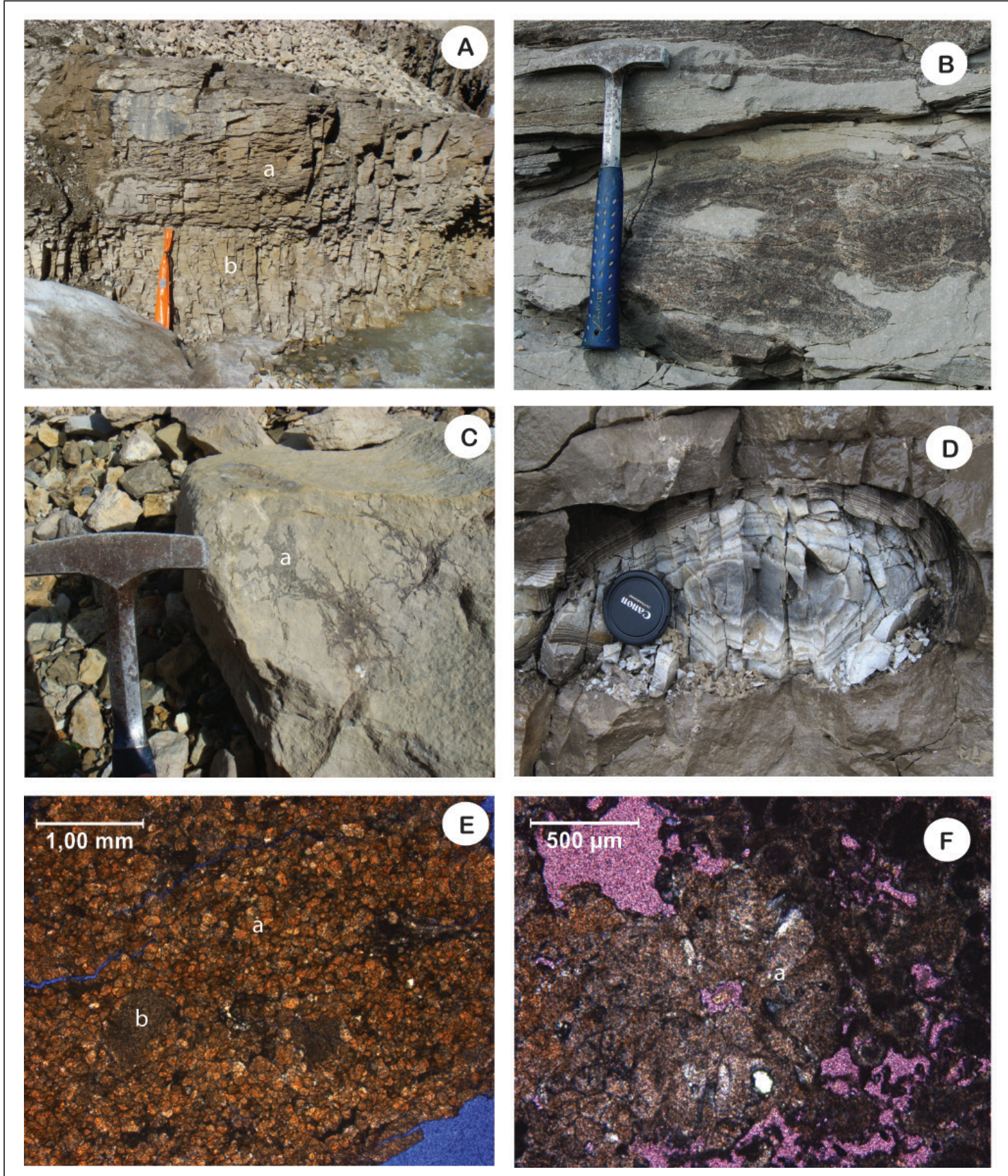

Figure 8. (A) (a) Massive Microcodium-overprinted facies caps. (b) An interval containing patchy Microcodium, Gangerrolvfjella. (B) Patchy overprinted Microcodium facies, Skansen. (C) (a) Microcodium networks, indications of root precipitation, Trollfuglfjella. (D) Concentric cherts are typical at $1 \mathrm{~m}$ below massive Microcodium-overprinted intervals, and may represent silcretes formed at the groundwater table. (E) Thin-section of massive overprinted Microcodium facies. Microcodium crystals (a) are yellow to brown calcite crystals with sweeping extinction. (b) Partially dissolved crinoid bioclast. (F) In situ Microcodium 'corn-cob'aggregate (a).

carbonate facies except the spiculite facies. Microcodium is particularly common in small foraminifer grainstone facies and at the top of thicker sandstones.

Interpretation: The Microcodium crystals are, in the literature, regarded as formed from calcification of mycorrhizal, a symbiotic association between fungi and cortical cells of plant roots (Klappa, 1978; Kosir, 2004; Kabanov et al., 2008). Consequently, the presence of Microcodium indicates terrestrial conditions and subaerial exposure, thus defining the termination of depositional cycles. Massive Microcodium horizons are regarded as extended subaerial exposure events and may be superimposed horizons reflecting several exposure events. Patchy horizons reflect shorter periods of subaerial exposure or the preserved lower part of an eroded Microcodium profile. 
The concentric chert layers below the Microcodium horizons are interpreted as silcretes that most likely formed at the groundwater table during exposure of the area.

\section{Caliche-overprinted facies}

Description: The caliche-overprinted facies comprises a suite of carbonate and siliciclastic sedimentary facies which are all characterised by distinct colour variations, mostly of red and white colours (Fig. 9). It is commonly associated with darker Microcodium networks that chaotically interfinger with the white caliche intervals but it is also associated with karstic horizons.

Thin-sections typically show a micritic matrix, strongly Fe-stained with micritised, marginally dissolved abiotic and biogenic grains. Solution seams, stylolites and cracks filled with calcitic cement are very common. Locally, the facies is fragmented or brecciated to form lithoclastic rudstones consisting of large, angular to more rounded, mudstone fragments composed of grey to dark coloured fossils of various types.

The most common caliche-overprinted microfacies are strongly altered and Fe-stained bryozoan - crinoid wackestones to packstones and small forminifera wackestones to packstones, but overprint is also seen in other facies types.

Occurrence: The caliche-overprinted facies is common in the lower Kapitol sequence 1 but is missing in the overlying part of the succession.

Interpretation: The caliche-overprinted facies represents originally marine deposits altered by meteoric, dolomitisation and pedogenesis processes during subaerial exposure. In places, fragmentation and brecciation are
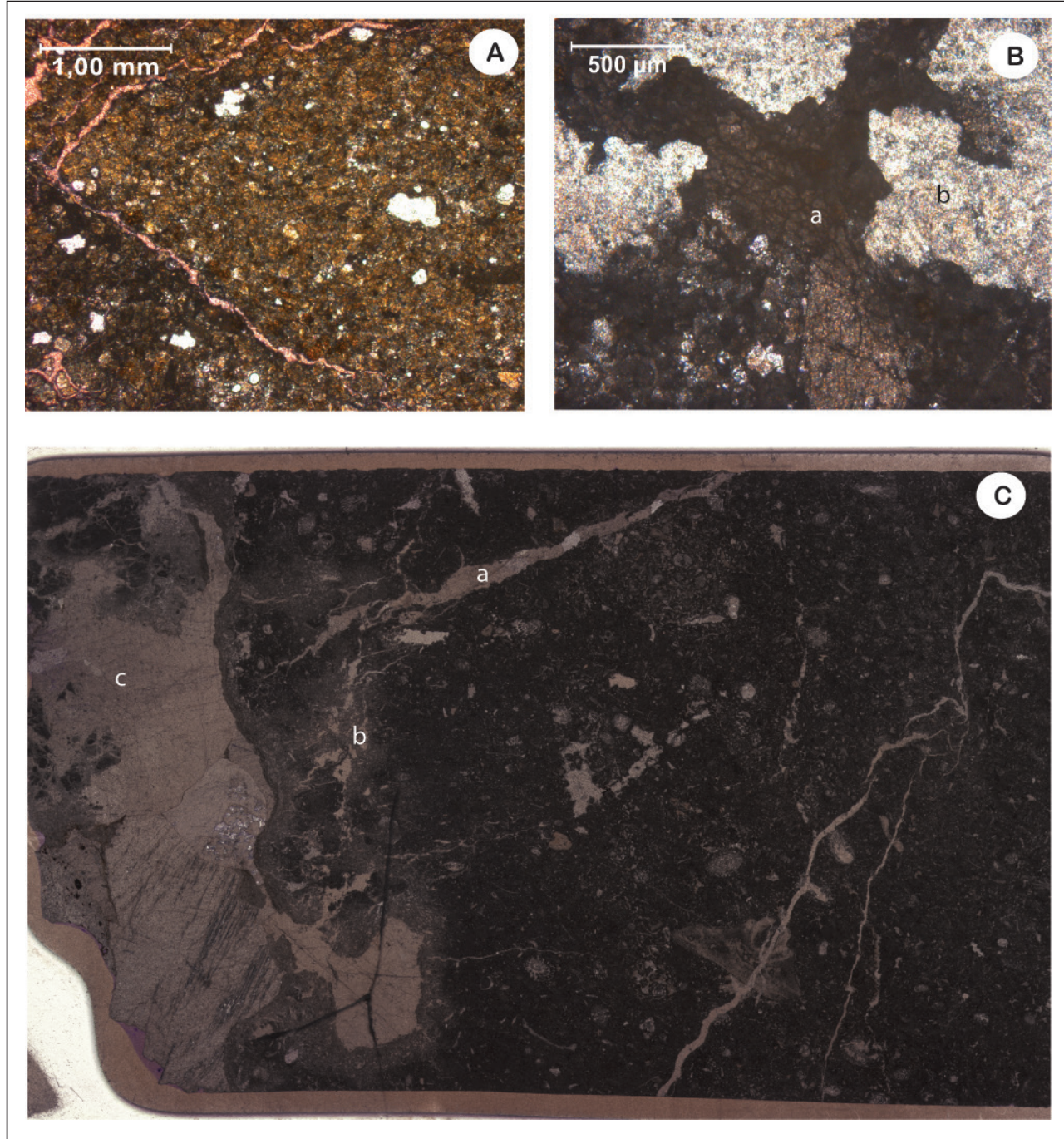

Figure 9. (A) Thin-section of caliche-overprinted facies. Structures related to root growth and decay are observed as round areas filled with sparry calcite surrounded by micritic coatings. (B) Thin-section of rhizocretions associated with aveolar septal fabric (a) formed by microbial encrustations. Sparry calcite (b). (C) Full thin-section of the caliche facies. (a) Sparry calcite-filled veins. (b) Rhizocretions associated with aveolar septal fabric. (c) Blocky cement. 
results of desiccation and shrinkage of the sediment under exposed semi-arid to arid climatic conditions. The distinct red coloration of the sediments is due to oxidisation of iron minerals while the white colours reflect the presence of carbonate nodules. The occurrence of root traces, carbonate nodules and Microcodium networks reflects the development of an immature paleosol likely during periods of slightly more humid conditions compared to the Microcodium-overprinted facies (Esteban \& Klappa, 1983; Wright, 1994).

\section{Sandstones}

Description: Up to $14 \mathrm{~m}$-thick beds of siliciclastic sandstones, carbonate-rich sandstones and conglomeratic sandstones form a characteristic part of the succession (Fig. 10). Conglomeratic sandstones are present at the base of the Wordiekammen Formation and at the base of the Tyrrellfjellet Member. Both these units are erosive. The most prominent sandstones are in the middle part of the Tyrrellfjellet Member, where they form two laterally widespread but generally poorly exposed units. The lower sandstone varies in thickness from less than 4 $\mathrm{m}$ in the east to up to $14 \mathrm{~m}$ in the west where it shows pronounced thickness variations, from 3 to $11 \mathrm{~m}$ within a strike length of $200 \mathrm{~m}$. The upper sandstone is less variable in thickness and is mostly around $7 \mathrm{~m}$ thick.

The lower sandstone is fine-grained and hummocky cross-stratified in outcrops along Billefjorden. In the down-dip areas, it is often characterised by a basal, finegrained, cross-bedded interval, a middle part of fine- to medium-grained sandstone with low-angle to planar cross-bedding, and an upper part of medium- to coarsegrained sandstone with horizontal lamination and abundant Microcodium - sometimes extending several metres into the sediment. At Trollfuglfjella, this unit displays considerable lateral thickness variations, up to $10 \mathrm{~m}$, and locally foresets up to $10 \mathrm{~m}$ high are preserved in the thicker sandstones.

The upper sandstone is also coarsening upwards from fine- to coarse-grained. It commonly shows large-scale planar cross-bedding locally with double mud drapes and in places shows herringbone cross-bedding. At Trollfuglfjella, small ponds between bar tops are filled with small sabkha cycles of mudstones with displacive gypsum nodules and enterolithically folded gypsum. Elsewhere, Microcodium is common. Bioturbation is locally common in the lower part.

In thin-section, the sandstones are characterised by fineto coarse-grained deposits dominated by well sorted, subangular to rounded quartz and biogenic grains. The biogenic grains are dominated by crionoids, Tubiphytes and brachiopods while encrusting foraminiferas are less common. All biogenic grains show indications of remobilisation and abrasion.
Occurrence: Several thin sandstones occur in the basal part of the succession particularly in the western areas. The prominent sandstone at the base of Tyrrellfjellet sequence 1 occurs mainly in the eastern part of the study area. Three distinct sandstone intervals are present in Tyrrellfjellet sequence 1 . They are traceable across the entire Nordfjorden High area although showing a very variable thickness (Fig. 5).

Interpretation: The sandstones are interpreted to reflect deposition in shallow-marine, storm- and tidaldominated environments based on the presence of crossbedding, HCS, herring-bone cross-stratification and double mud drapes. The sandstones and conglomeratic sandstones at the base of the formation and at the base of the Tyrrellfjellet Member are both overlying subaerial exposure surfaces with evidence of erosion, and these units are interpreted as transgressive shoreface deposits in accordance with Dons (1983).

In contrast, the upward-coarsening sandstones in the middle part of the Tyrrellfjellet Member rest on marine carbonates and are capped by features indicative of subaerial exposure (Microcodium). In the up-dip areas to the east, Microcodium-capped hummocky crossstratified sandstones are interpreted to reflect deposition above storm wave-base followed by subaerial exposure. Farther to the west, more accommodation space was available and tidally influenced bars are preserved. Both sandstones reflect forcing of siliciclastics across the carbonate-dominated ramp and eventually subaerial exposure, and in contrast to the majority of the carbonate facies they reflect deposition above wave base. We suggest that they represent a forced regressive event. However, the sudden arrival of two siliciclastic sandstones on the carbonate-dominated central Spitsbergen platform is a puzzle. It is generally accepted that Spitsbergen and the adjacent Barents Shelf were sites of carbonate platform deposition during the Asselian and no obvious source areas are known (Steel \& Worsley, 1984; Stemmerik et al., 1995; Harland \& Geddes, 1997; Samuelsberg \& Pickard, 1999; Stemmerik, 2000; Larssen et al., 2005; Worsley, 2008). The sandstones can be traced eastwards across the Billefjorden Fault Zone to Bünsow Land (Dons, 1983; Samuelsberg et al., 2000), and it has been suggested that the source area was located in the north or northeast (Lauritzen et al., 1989). The fine grain size of the sand has led us to speculate if the sand is a reworked aeolian sand from dune fields which became flooded during $3^{\text {rd }}$-order transgressions and reworked across the ramp during the following fall in sea level.

\section{Laminated to wavy mudstones}

Description: This facies consists of finely, planarlaminated, white to light-grey dolomites with some wavy laminations (Fig. 11). The laminae are $0.1-0.5 \mathrm{~mm}$ thick and separated by thin bituminous films. Fenestrate porosity and birds eyes are occasionally present and 


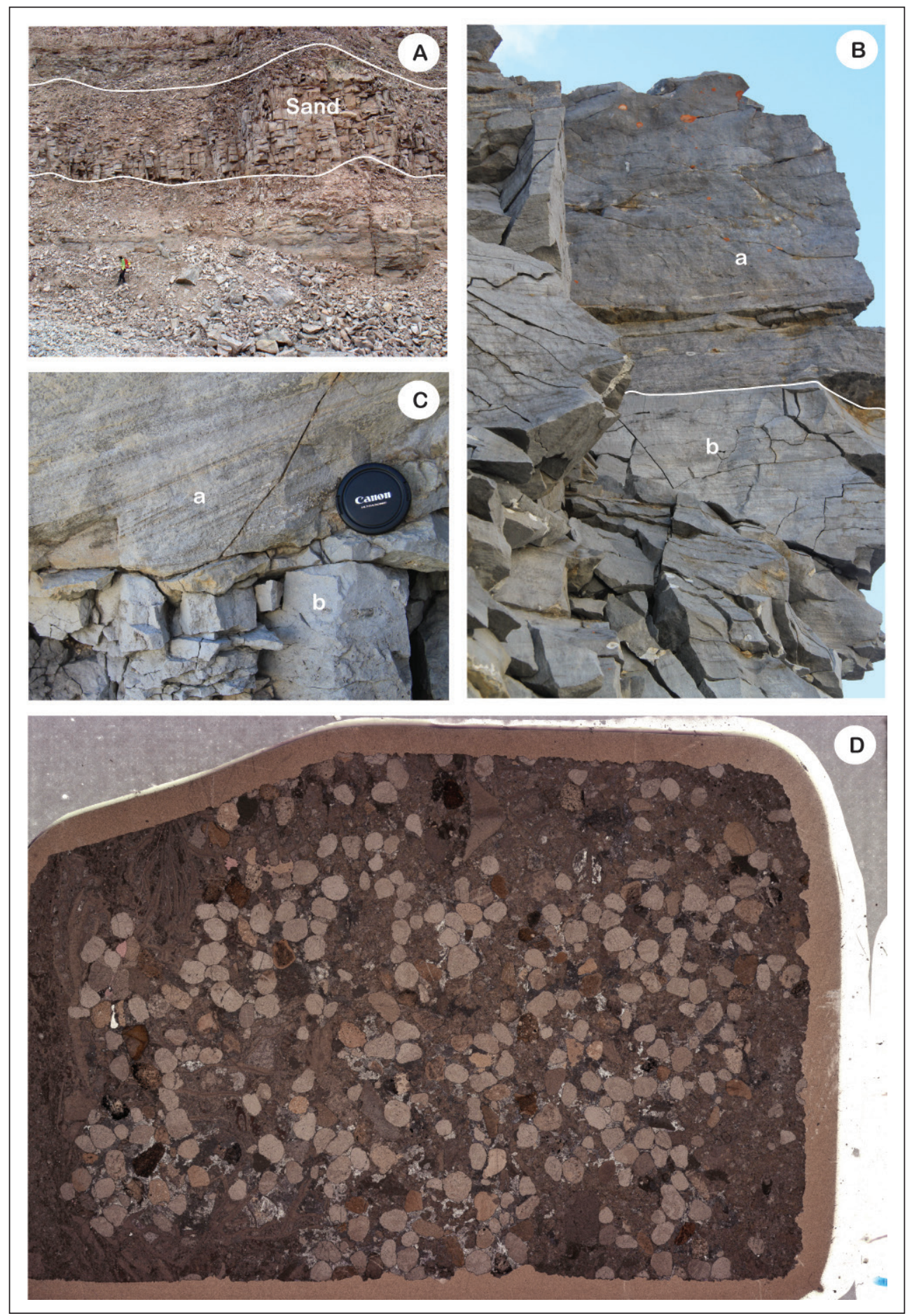

Figure10. (A) Photo of the cliff-forming sandstone 2 interval, Trollfuglfjella. (B) Top of sandstone 2 interval, Torfjella. (a) Massive Microcodiumoverprinted sandstone at the top of sandstone interval 2 (b). (C) Basal erosive contact of sandstone 2 interval and the underlying carbonate succession (b), Torfjella. (a) Sandstone clinoforms are clearly defined by vugs after dissolved carbonate bioclasts. (D) Full thin-section of the sandstone facies. The facies is dominated by rounded to subrounded quartz crystals and various carbonate bioclasts.

displacive gypsum nodules occur at one locality. Here, thin evaporites in nodular to rare chicken-wire structures are characteristic features of the facies. Locally, more prominent and thicker evaporite layers have brecciated the carbonate layers.

No macro fossils have been observed in the facies.
Occurrence: The laminated to wavy mudstones are very rare, limited to the base of Tyrrellfjellet sequence 2 in the distally located Trollfuglfjella and Gangerrolvfjella sections. Evaporite nodules occur only in the Gangerrolvfjella section. The occurrence correlates to a karstic surface in the up-dip sections. 


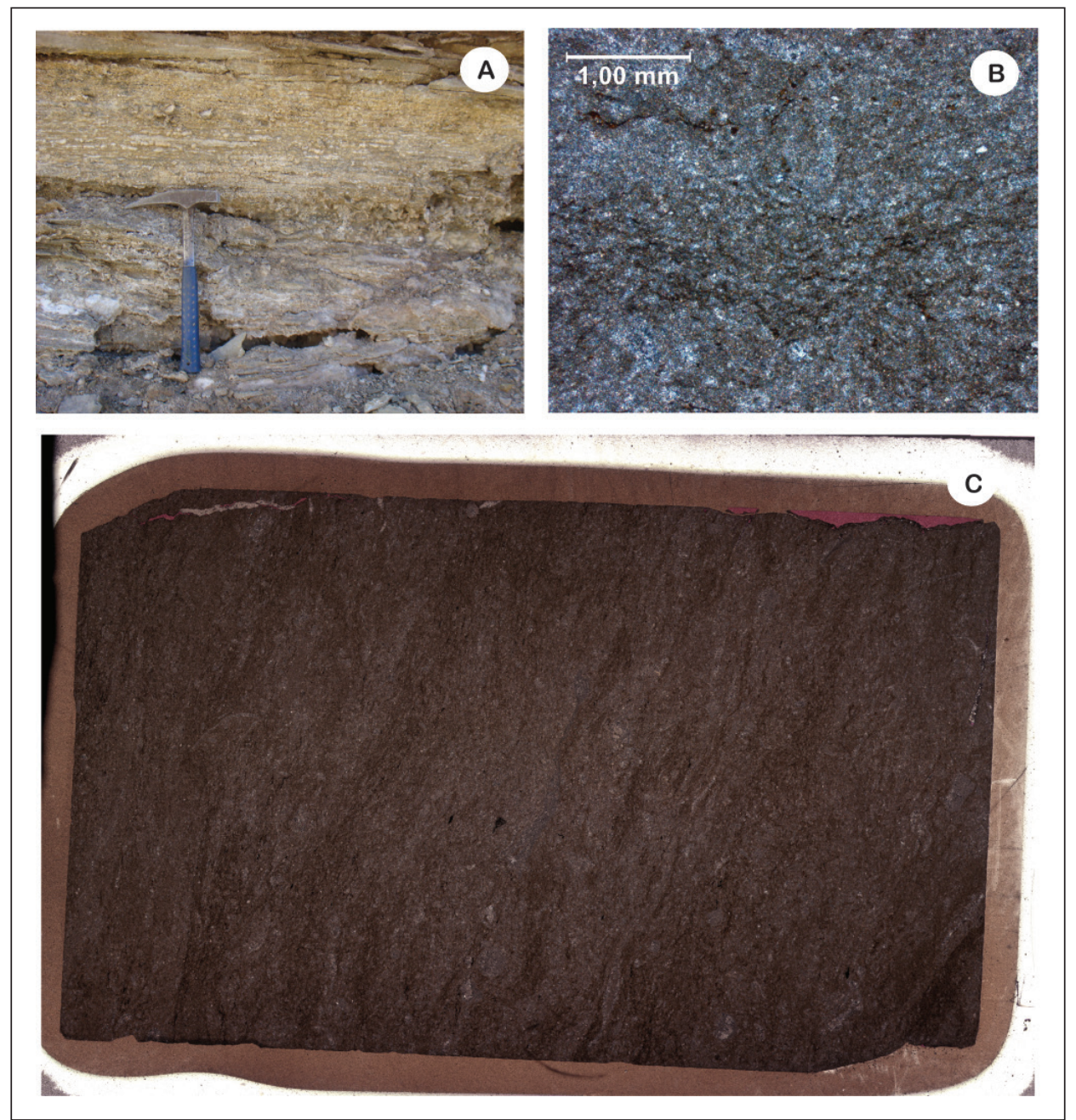

Figure 11. (A) Photo of laminated to wavy mudstone interbedded with evaporite nodules, Top Gangerrolvfjella. (B) Thin-section of laminated to wavy mudstones. Brown laminae represent bituminous films. (C) Full thin-section of the facies visualising wavy laminae. These formed due to microbial algal mat growth in an intertidal environment.

Interpretation: The characteristic horizontal to wavy lamination is interpreted as having formed by microbial or algal mats and the presence of birds eyes, fenestrate porosity and more rarely nodular gypsum indicates deposition in intertidal- to supratidal settings (Esteban \& Klappa, 1983; Shinn, 1983). The facies is comparable with the laminated facies (dololaminites and microbial structures) of Hüneke et al. (2001) and the microbial limestone facies of Blomeier et al. (2011), both described from carbonates of the central Spitsbergen area.

\section{Small Foraminifera wackestone to grainstone}

Description: The small foraminifera facies ranges from well-sorted wackestones to grainstones. The biogenic assemblage is composed of abundant small benthic foraminiferas, most commonly encrusting apterrinellids and Tubertirina, less important paleotextulariids and bradyinids while tetrataxids are rare. The green algae Beresella is also common, mostly as fragmented or dissolved grains where the outlines of the dissolved
Beresella voids are defined by encrusting Tubiphytes and foraminiferas. Gastropods are rare, but when observed they dominate along with apterrinellid foraminiferas. These abundant contributors are often associated with Tubiphytes and more rarely crinoids, brachiopods, fenestrate bryozoans, fusulinids, ostracods and micritised gains. Subrounded silt to fine-sand quartz grains and peloids are also present (Fig. 12).

Occurrence: This facies is widely distributed in the Wordiekammen succession but is predominant in the lowermost part of the Tyrrelfjellet sequence 1 in the distal area towards the west.

Interpretation: The dominance of green algae and small foraminiferas suggests deposition in somewhat stressed, shallow-water environments likely with increased salinity (Wilson, 1975; Burchette \& Wright, 1992; Flügel, 2004). The presence of common micritised grains indicates slow rates of deposition (Flügel, 2004). Accordingly, this facies is interpreted to represent deposition in a range of 
shallow, inner-shelf environments, including lagoons. Overall it is characterised by low biogenic diversity with some beds with higher diversity suggesting temporary shifts in depositional conditions. In particular, the occurrence of paleotextulariids and bradyinids together with brachiopods, fenestrate bryozoans and calcispheres is likely to reflect events of more normal marine conditions.

The facies is interpreted to be similar to the smallforaminifera facies of Hüneke et al. (2001), the foraminiferal facies of Morin et al. (1994) and the smallforaminifera facies of Blomeier et al. (2011).

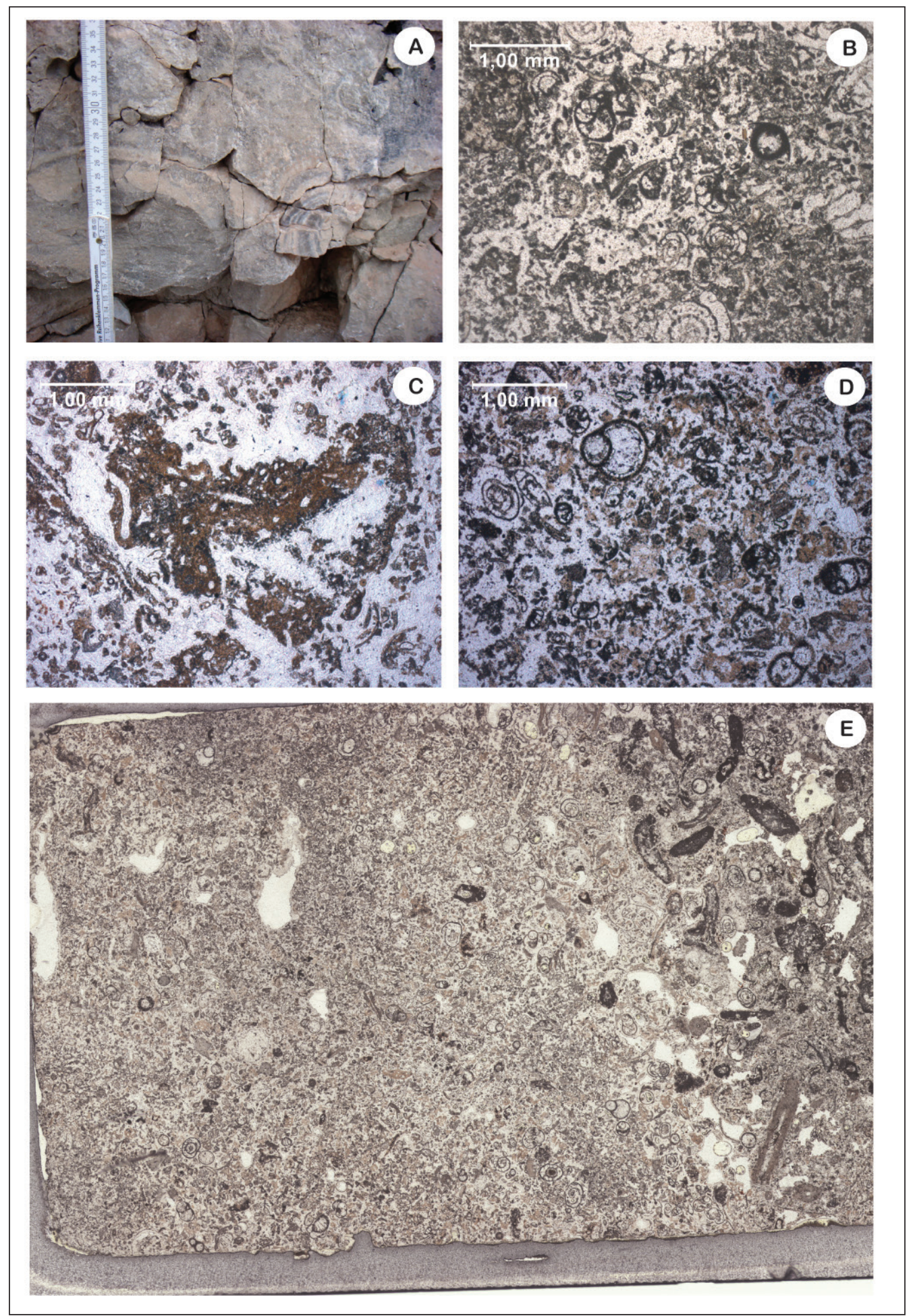

Figure 12. (A) Outcrop showing the small foraminifera facies, Trollfuglfjella. Concentric chert is present in a siliciclastic interval. (B) Polished thinsection of the silicified interval of photo (A). The facies is dominated by small apterrinellids, paleotextulariids and other less important foraminiferas. (C) Encrusting colony of apterrinellids. The encrustisation outlines dissolved beresella cavities. (D) Small foraminifera facies, here dominated by Tubertirina, apterrinellids and beresella bioclasts. (E) Full thin-section of the small foraminifera packstone to grainstone. The facies is dominated by well sorted foraminiferas but also includes red algae (larger dark fossils). 


\section{Oolitic grainstones}

Description: This facies is represented by up to $4 \mathrm{~m}$ thick units of low-angle, planar cross-bedded oolitic grainstones (Fig. 13). It is dolomitised and most allochems are dissolved. The oolitic facies is overprinted by Microcodium.

In thin-section, this facies is dominated by well-sorted ooids and biogenic grains, mainly foraminiferas, beresellids and fusulinids. The ooids are up to $0.5 \mathrm{~mm}$ and composed of several concentric laminae, while superficial oolitic grainstones have been observed in some places. The biogenic grains are abraded and show signs of transportation. Detrital silt to fine-sand size quartz grains and peloids are common.

Occurrence: Oolitic grainstones are rare, except in the upper part of Tyrrellfjellet sequence 2. This is in accordance with observations from the Wordiekammen
Formation elsewhere on Svalbard and data from the time-equivalent offshore succession (Bugge et al., 1995; Pickard et al., 1996; Ehrenberg et al., 1998; Hüneke et al., 2001; Blomeier et al., 2008).

Interpretation: This facies represents deposition in a shallow-marine high-energy environment above wave base. This is supported by the presence of cross-bedding and dominance of biogenic grains typical of inner shelf and shoal environments (Burchette \& Wright, 1992). The mixture of ooids and abraded biogenic grains may indicate that the ooids were reworked into more quiet settings.

The oolitic grainstone facies is missing in most of the depositional cycles of the Wordiekammen Formation, indicating either that the setting was not favourable for oolite formation or that preservation of sediments deposited above wave base was rare (e.g., Stemmerik, 2008).
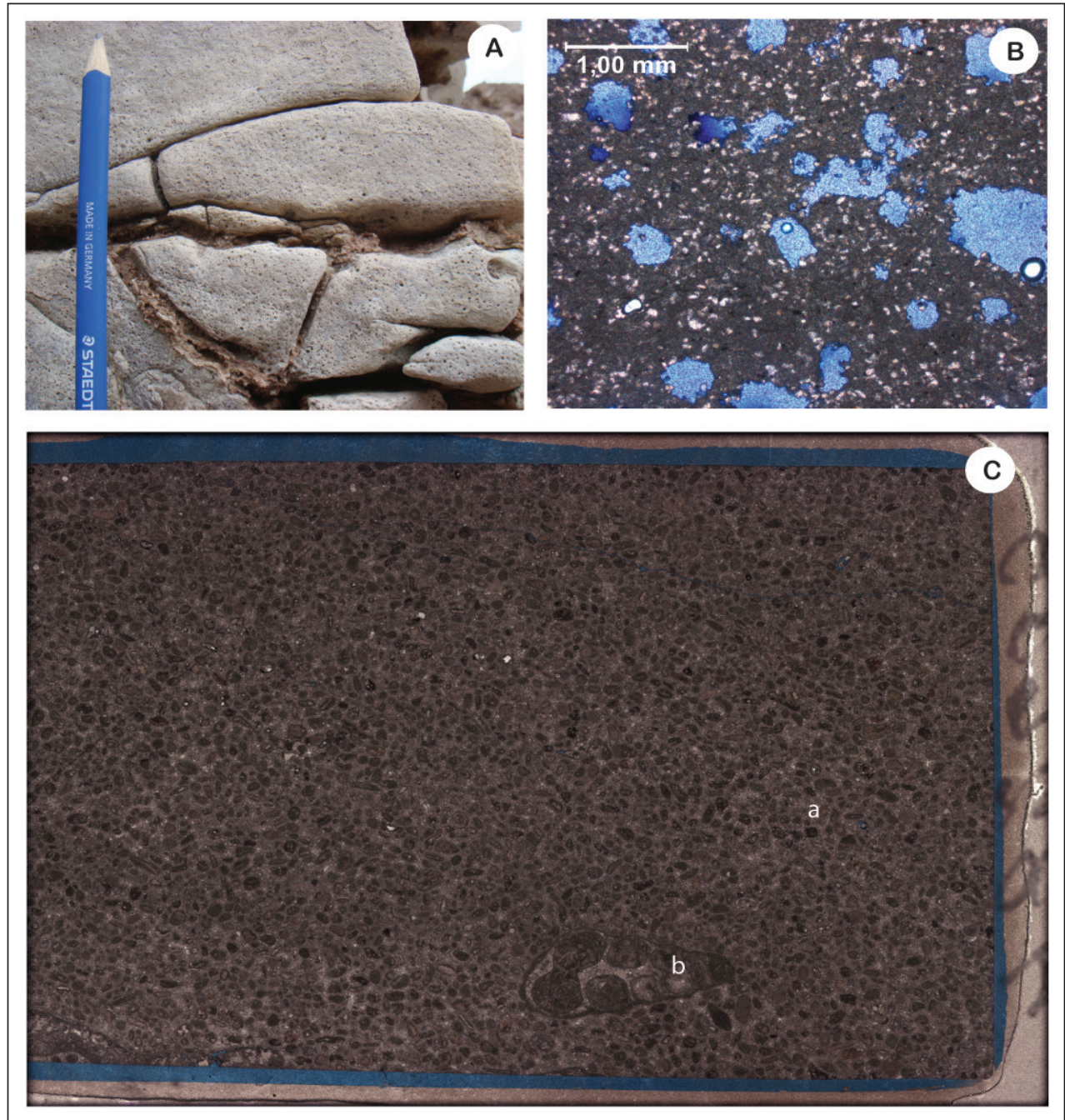

Figure 13. (A) Dolomitised oolitic grainstone, Top Trollfuglfjella. (B) Dolomitised oolitic wackestone with abundant detrital quartz grains. The ooids are dissolved and filled by blue epoxy visualising porosity. (C) Full thin-section of oolitic grainstone. (a) Oolitic grainstones. (b) Gastropod. 


\section{Beresellid-dominated packstones and grainstones}

Description: The facies consists of light grey, well-sorted packstones to grainstones. The dasyclad algae Beresella dominates and small foraminiferas such as apterrinellids, paleotextulariids and Tubertirina are abundant, whereas silt-size subrounded quartz grains and peloids are rare. Beresella occurs as highly fragmented grains and is often seen as dissolved voids outlined by encrusting foraminiferas and Tubiphytes. Crinoids, brachiopods, fusulinids, calispheres, ostracods and less common trilobites are also present in some places in this facies.

Occurrence: The Beresellid packstones and grainstones form a minor component of the Kapitol Member and Tyrrellfjellet sequence 1 of the Nordfjorden High. This facies is closely associated with the fusulinid-crinoid facies.

Interpretation: The Beresella packstones and grainstones are interpreted as shallow-water, inner-ramp sediments deposited above fair weather wave base. This is based on the strong light dependence of dasyclad green algae, the abundance of small benthic foraminiferas, lack of carbonate mud and well-sorted textures. The facies is characterised by a highly diverse biotic assemblage suggesting a more circulated, open marine, depositional environment than the lagoonal environment of the small foraminifera facies. It has much in common with the small foraminifera facies and is accordingly interpreted to reflect deposition in a shallow inner-ramp environment. The Beresella packstones and grainstones have been interpreted to be similar to the Dasycladacean Facies recognised by Morin et al. (1994).

\section{Fusulinid-crinoid wackestones and packstones}

Description: The fusulinid-crinoid wackestones and packstones are medium-bedded, grey to dark grey, commonly bioturbated, and locally with more prominent layers of chertified Thalassinoides burrows (Fig. 14). In thin-sections, the bioclastic wackestones and packestones are poorly to moderately sorted with common fusulinids and crinoids, some brachiopods, fenestrate bryozoans, apterrinellid and less common paleotextulariids, Tuberitina and bradyinid foraminiferas. Beresellids and Tubiphytes are also important components while ostracods, sponge spicules, trilobites and rugose corals are rare. Bioclasts are often abraded.

Occurrence: The Fusulinid-crinoid facies is widely distributed in the Wordiekammen succession and very common in the Tyrrellfjellet sequence 1 where it is associated with the Paleoaplysina bioherm and fusulinid facies.

Interpretation: The fusulinid-crinoid wackestones and packstones have the most diverse biogenic assemblage recognised in the Wordiekammen carbonates. The dominance of fusulinids and crinoids and the abundance of brachiopods and bryozoans indicate deposition in fully marine environments.

The presence of beresellids and small foraminiferas indicates a proximity to the small foraminifera facies and the abundance of encrusting foraminifera and abraded and coated grains is taken as evidence of storm reworking. The fusulinid-crinoid facies is closely related to the beresellid facies but may represent a more distal depositional setting based on the higher biological diversity, presence of various bryozoans and a decrease in the beresellid content.

The facies is similar to the bioclastic packstone/ wackestones facies recognised by Hüneke et al. (2001) and the fusulinid-foraminifera facies described by Blomeier et al. (2008) which both were adapted to a wide spectrum of living environments from open marine nearshore to deeper subtidal conditions.

\section{Paleoaplysina floatstones and bindstones}

Description: Paleoaplysina floatstones and bindstones form isolated lenticular mounds, 0.5 to $3 \mathrm{~m}$ thick and several hundred metres wide, and tabular buildups 0.5 to $10 \mathrm{~m}$ thick and several kilometres in width(Figs. 15, 16). The Paleoaplysina floatstones are loosely packed and composed of chaotically packed abraded plates encrusted by foraminiferas, Tubiphytes and fenetrate bryozoans. Brachiopods, crinoids and fusulinids are abundant. The internal channel system is very distinctive and filled with well-sorted peloids, mud and small encrusting apterrinellids and Tubiphytes.

The Paleoaplysina bindstones are densely packed by Paleoaplysina plates with rare fenetrate bryozoans.

The Paleoaplysina plates are $2-5 \mathrm{~mm}$ thick and up to 20 $\mathrm{cm}$ long and easily recognised by their internal channel system (Figs. 15A, 16D).

The bioherms form the upper part of cycles starting with thin, basal, small foraminifera wackestones to grainstones followed by a thin, bryozoan-crinoid wackestone with colonies of rugose corals and multithecoporids. The lower core of the bioherm is composed of densely packed Paleoaplysina bindstones whereas the uppermost part of the bioherm consists of muddy Paleoaplysina floatstones. The bioherms are generally capped by a Microcodium-overprinted horizon and the Paleoaplysina bindstones and floatstones are often intensely dolomitised and preserved as yellow and brown dolomites with a vuggy and intercrystalline porosity. In places, the Paleoaplysina plates are completely dissolved resulting in highly brecciated bioherms with high porosity and permeability. 

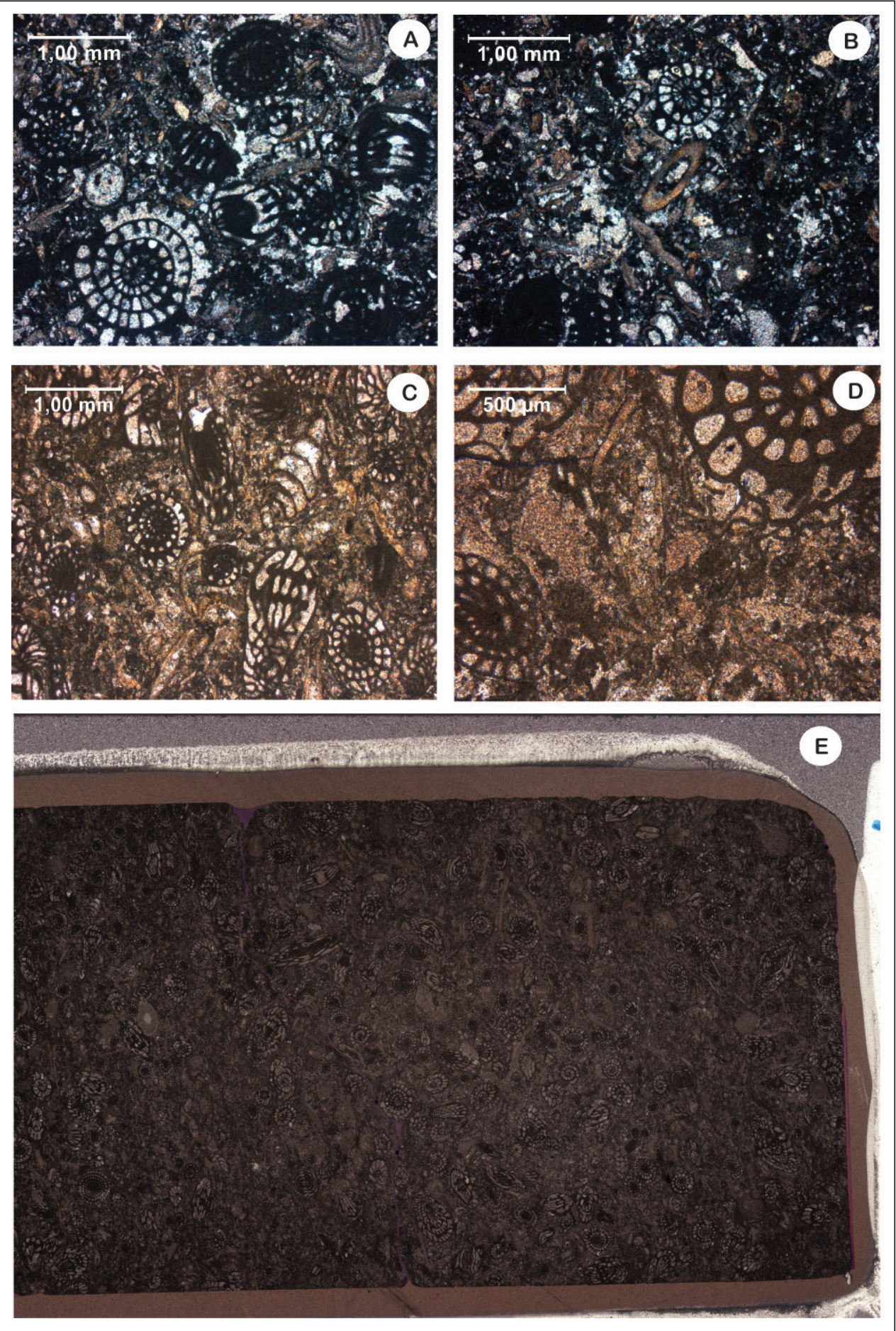

Figure 14. Thin-sections of fusulinid-crinoid packstone. (A) Fusulinid-crinoid packstone dominated by fusulinids with some crinoids and fenestrate bryozoa. (B) Fusulinid-crinoid packstone dominated by fusulinids, brachiopods, crinoids and paleotextulariids. (C) Fusulinid-crinoid packstone. Fusulinids dominate and crinoids, foraminiferas, brachiopods and more rare beresella are also observed. (D) Fusulinid-crinoid packstone dominated by fusulinids and crinoids with crushed ostracods. (E) Full thin-section of the facies.

Occurrence: The Paleoaplysina bioherms are found in three distinct intervals in the Tyrrellfjellet sequence 1. The lowermost bioherm interval has successfully been traced over the entire Nordfjorden High whereas the two upper bioherm intervals are confined to the up-dip and crestal parts of the study area. The three bioherm intervals are thickest and best developed in the crestal areas to the east and thin westwards.
Interpretation: The Nordfjorden High buildups all show a characteristic succession of facies starting with rare Paleoaplysina plates overlying coral floatstones and/ or Bryozoan-crinoid facies. The core of the buildups consists of Paleoaplysina bindstones representing the colonial stage. Plates are all well preserved and show little evidence of abrasion suggesting deposition below storm wave base. The upper part of the bioherms is 

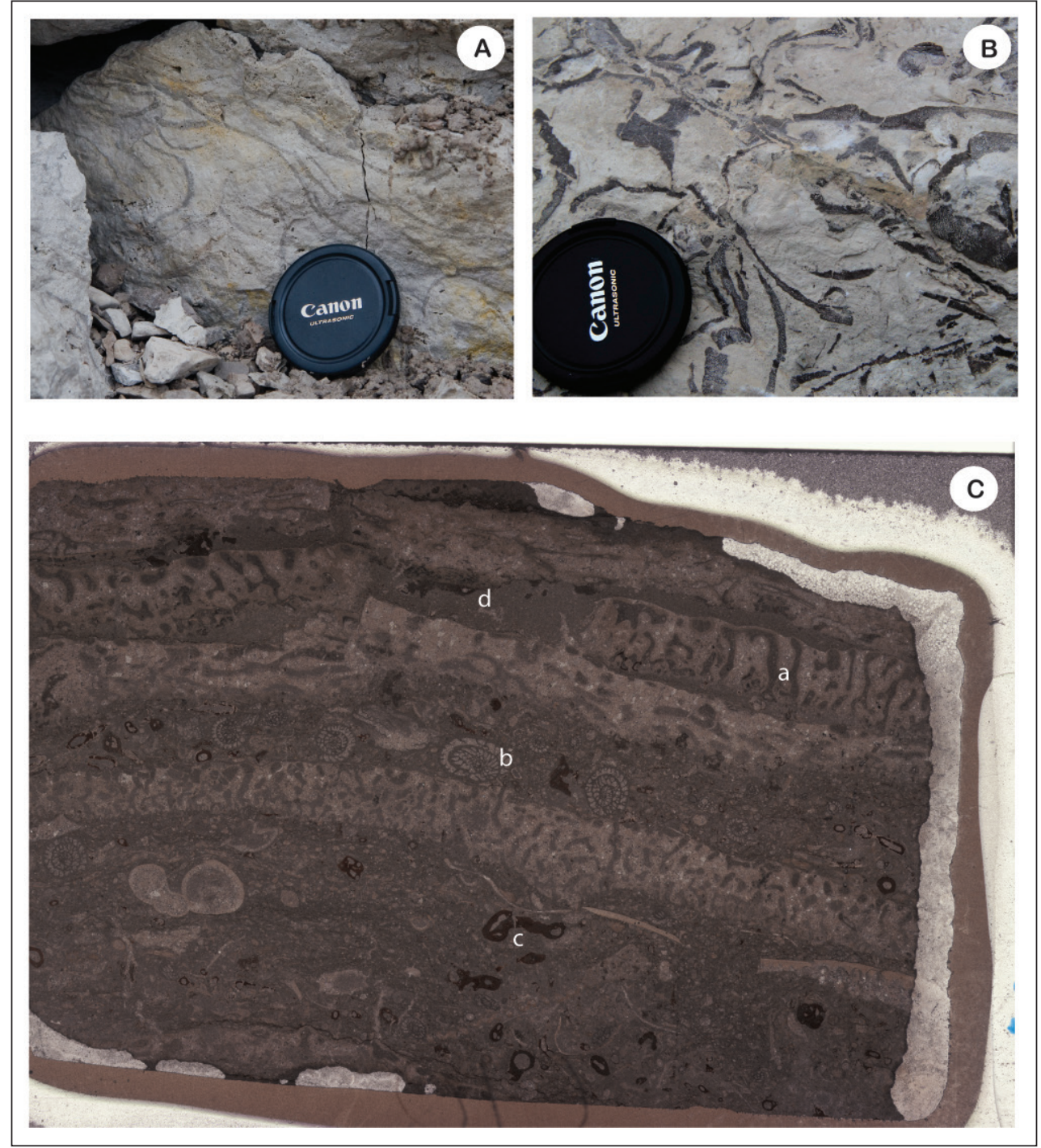

Figure 15. (A) Outcrop interval dominated by dolomitised Paleoaplysina floatstones, Yggdrasilkampen S. (B) Dolomitised Paleoaplysina floatstones with replaced Paleoaplysina plates. (C) Full thin-section of the Paleoaplysina floatstone facies. (a) Paleoaplysina plates with distinct internal channel systems. (b) Small fusulinids. (c) Encrusting Tubiphytes. These are commonly observed encrusting the surfaces of individual Paleoaplysina plates (d).

dominated by Paleoaplysina floatstones with abundant abraded Paleoaplysina plates encrusted by foraminifera and Tubiphytes, suggesting that the bioherm grew near to the storm wave base. Accordingly, the Paleoaplysina facies seem to occupy a range of environmental settings limited upwards by the storm wave base. They are interpreted as mound accumulations, in accordance with Skaug et al. (1982), forming lenticular and tabular bioherms that are believed to have formed in deeper open marine environments based on the presence of muddy bryozoan-crinoid wackestones at the base of each bioherm cycle.

The bioherm tops are capped by Microcodiumoverprinted horizons indicating subaerial exposure.

The Paleoaplysina floatstones and bindstones have been interpreted as similar to the Palaeoaplysinid Boundstone
Facies recognised by Hüneke et al. (2001) and the Palaeoaplysina mound facies of Blomeier et al. (2008), while the floatstones and the bindstones resemble the Paleoaplysina wackestones and Paleoaplysina boundstones described by (Hanken \& Nielsen, 2013).

\section{Fusulinid wackestones}

Description: Fusulinid wackestones form 0.5-6 $\mathrm{m}$-thick, dark to black, laminated to massive carbonates dominated by large fusulinids (Fig. 17). Locally, the faciest is interbedded with shales rich in fusulinids.

In addition, rare rugose corals, ostracods, foraminiferas, crinoids, brachiopods and bryozoans are present. The facies is locally very organic-rich containing 1-15\% TOC (Dons, 1983; Dallmann, 1999). 

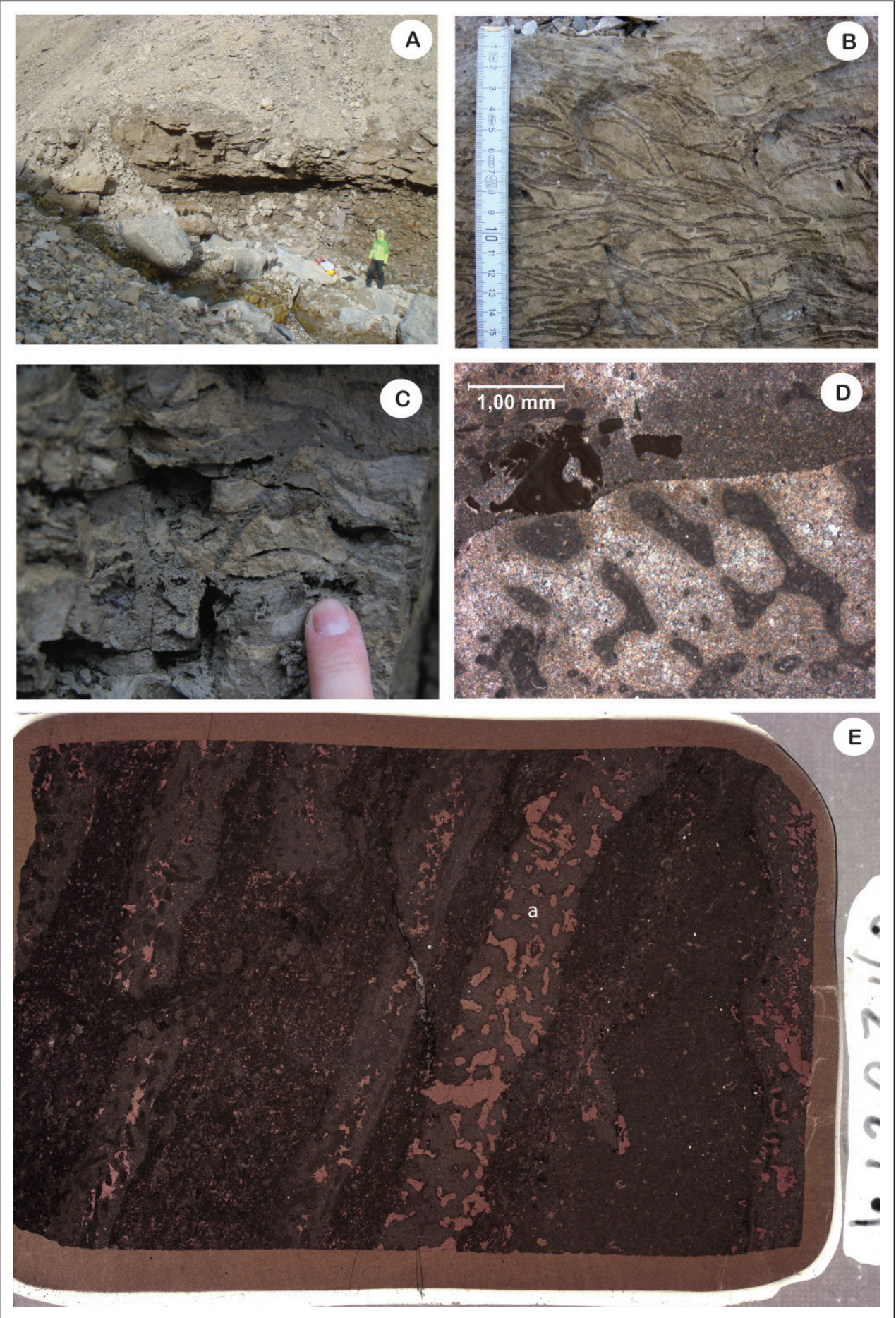

Figure 16. (A) Paleoaplysina bioherm 1, Asvindalen. (B) Photograph of Paleoaplysina bindstone, Paleoaplysina bioherm 1, Asvindalen. (C) Dolomitised Paleoaplysina bindstone. Paleoaplysina plates are partially dissolved creating a vuggy secondary porosity. (D) Thin-section of Paleoaplysina bindstone. Note the internal channel systems of the plates and sporadic encrusting Tubiphytes. (E) Full thin-section of dolomitised Paleoaplysina bindstone. Paleoaplysina plates are partially dissolved creating a promising secondary porosity of intercrystalline and vuggy types.

Occurrence: The Fusulinid wackestones occur mostly in Tyrrellfjellet sequence 1 and have been defined as the Brucebyen Beds (Cutbill \& Challinor, 1965; Dallmann, 1999). They are widespread over much of central Spitsbergen forming a highly diachronous unit according to biostratigraphical data in Nilsson (1993). The Brucebyen Beds are closely related to the Paleoaplysina bioherms.
Interpretation: The abundant mud and the presence of an open marine fauna indicate that the fusulinid wackestones were deposited in a low-energy subtidal setting. The high levels of organic matter further indicate dysaerobic to anoxic bottom waters and might reflect times of restriction in water circulation and slow sedimentation. Since fusulinids are considered to be 

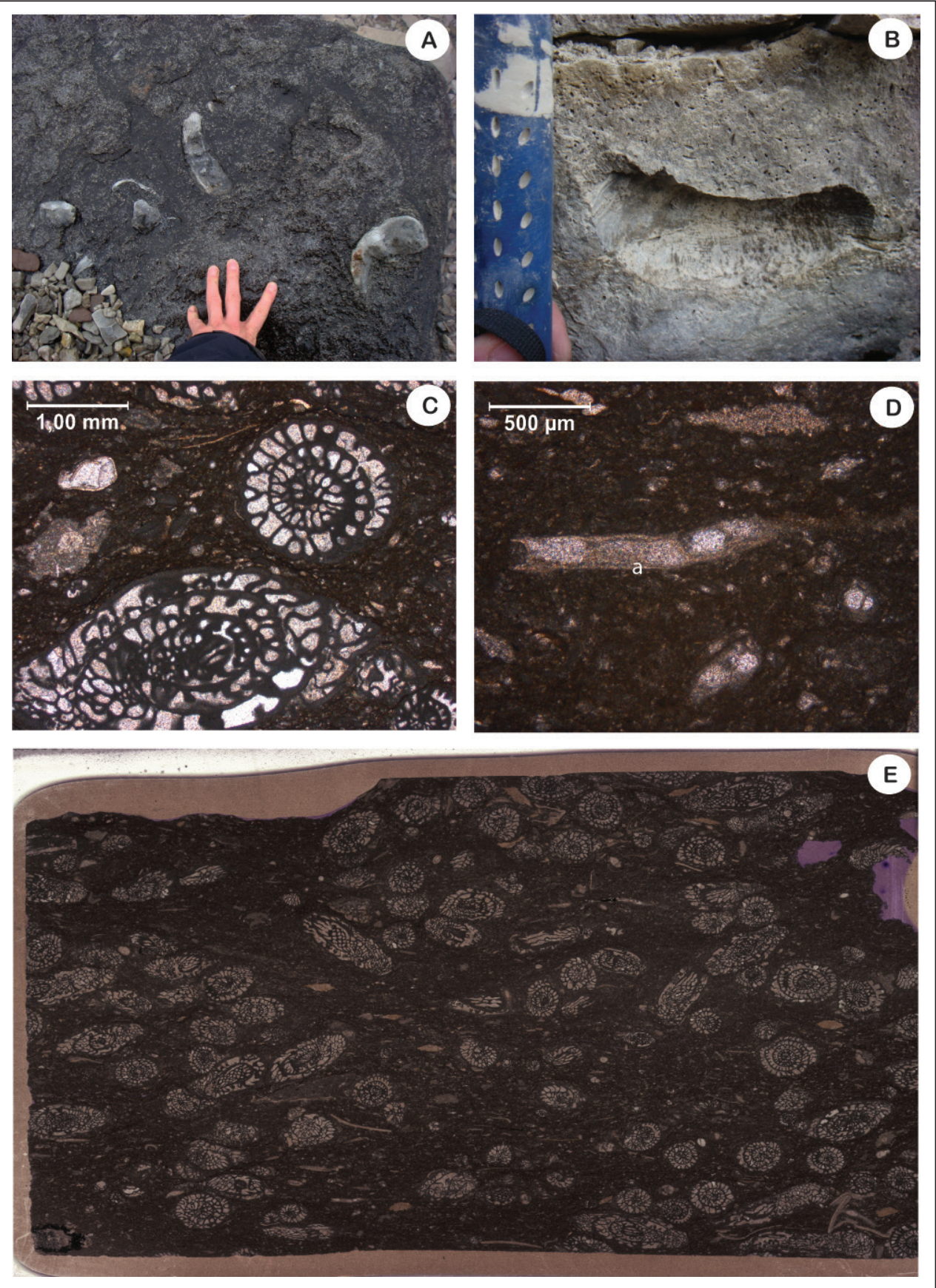

Figure 17. (A) Fusulinid wackestones of the Brucebyen Beds containing large solitary corals, Trollfuglfjella. (B) Dolomitised Brucebyen Beds, Asvindalen. Small and large vugs from dissolved fusulinids and solidary corals are common features in the facies. (C) Thin-section of the Fusulinid wackestone, Brucebyen Beds, Trollfuglfjella. Well preserved fusulinids dominate while crinoids, foraminiferas and fenestrate bryozoans are less common. (D) Fenestrate bryozoan (a). (E) Full thin-section of the Brucebyen Beds, Trollfuglfjella. The brownish colour of the matrix reflects the high organic content.

fully marine, living in symbiosis with light-dependent cyanobacteria (Ross \& Ross, 1991), it is likely that they were reworked basinwards from adjacent buildups or shallower parts of the ramp during storm events as proposed by Samuelsberg et al. (2000).The absence of tempestite beds within the sediment suggests some degree of bioturbation, although it has to have been minor due to the high TOC content.

\section{Coral floatstone}

Description: The coral floatstone facies consists of laterally continuous horizons of isolated rugose corals and multithecoporids (Fig. 18). The colonies are up to $15 \mathrm{~cm}$ high and $50 \mathrm{~cm}$ wide and commonly directly overlie karst or Microcodium-overprinted units. In thinsection, the groundmass is generally a packstone rich in encrusting apterrinellids and less common crinoids and brachiopods. 


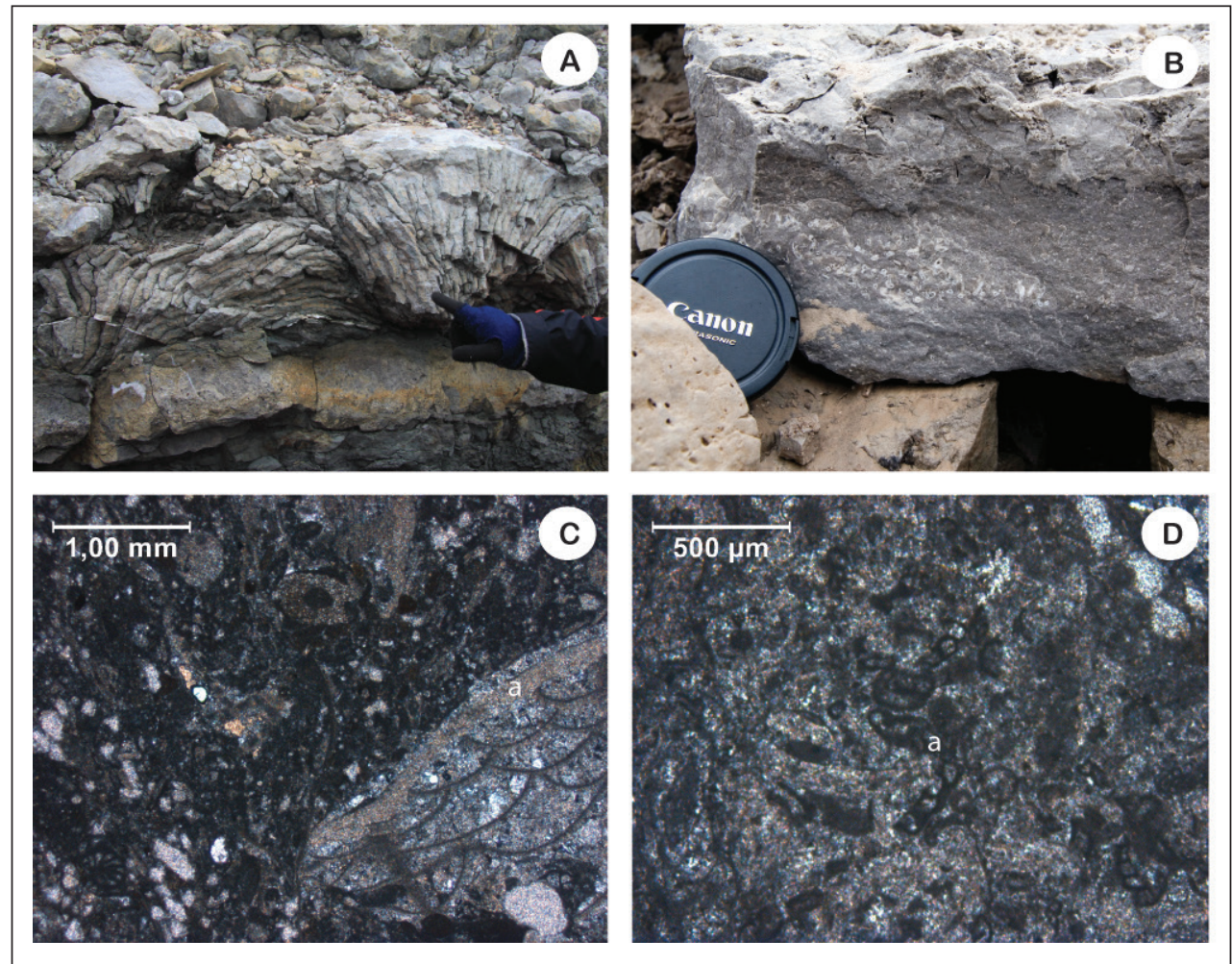

Figure 18. (A) Coral floatstone facies, photograph taken of the most evolved Coral floatstone facies observed, here from Brøggerhalvøya. Large colonies of rugose corals and multithecoporids dominate the lower parts of the facies interval directly on top of a dolomitised subaerial exposure surface. (B) Grey coral floatstone facies dominated by multithecoporids, Yggdrasilkampen S. This is very common in the lowermost part of the depositional cycles of the Wordiekammen succession. (C) Thin-section of the coral floatstone facies. (a) Rugose coral. The facies is dominated by rugose corals, foraminifera, beresella and crinoids with a matrix consisting mostly of peloids and detrital quartz. (D) Apterrinellids (a) constitute the dominant group of foraminiferas in the facies.

Occurrence: The coral floatstones are observed throughout the Wordiekammen succession where they form stratigraphic marker beds that can be correlated over much of the study area.

Interpretation: The coral floatstones are interpreted to represent the early stages of flooding following periods of subaerial exposure. The multithecoporids and rugose corals formed a pioneer fauna during each stage of flooding before a more diversified marine life became established. The coral floatstones are similar to facies described from Bjørnøya and the Finnmark Platform (Ehrenberg et al., 1998) where the coral-dominated horizons are interpreted as transgressive intervals.

\section{Brachiopod facies}

Description: The Brachiopod facies is, in outcrop, characterised by grey, medium- to thick-bedded carbonate packstones to floatstones dominated by large and small brachiopods and crinoids. The facies is bioturbated by Thalassinoides and Zoophycos, and Thalassinoides is commonly present as chert nodules or continuous chert layers.

In thin-section, the facies is characterised by moderately sorted mudstones to packstones with a relatively low biogenic diversity dominated by brachiopods. Crinoid and fenestrate bryozoans are also common, and brachiopod spines are locally very common.

Occurrence: The Brachiopod facies is rare in the study area, most common in the Tyrrellfjellet sequence 2 .

Interpretation: Based on the presence of carbonate mud, the lower diversity and the Bryonoderm biogenic assemblage, this facies is interpreted to reflect deposition in a deeper and cooler depositional environment below the fair-weather wave base. This is in line with the interpretation of Hüneke et al. (2001).

\section{Bryozoan-crinoid wackestones to packestones}

Description: The bryozoan-crinoid wackestones to packstones consist of medium-bedded, dark grey carbonates showing a distinctive biomottled appearance due to bioturbation (Fig. 19). Nodular and/or layered cherts are characteristic for this facies and chert commonly fills original Thalassinoides burrows in 5-25 $\mathrm{cm}$-thick complex layers. Also, abundant 1-10 cm-thick, crinoid-dominated, packstone beds are common. They are densely packed and generally have an irregular and 

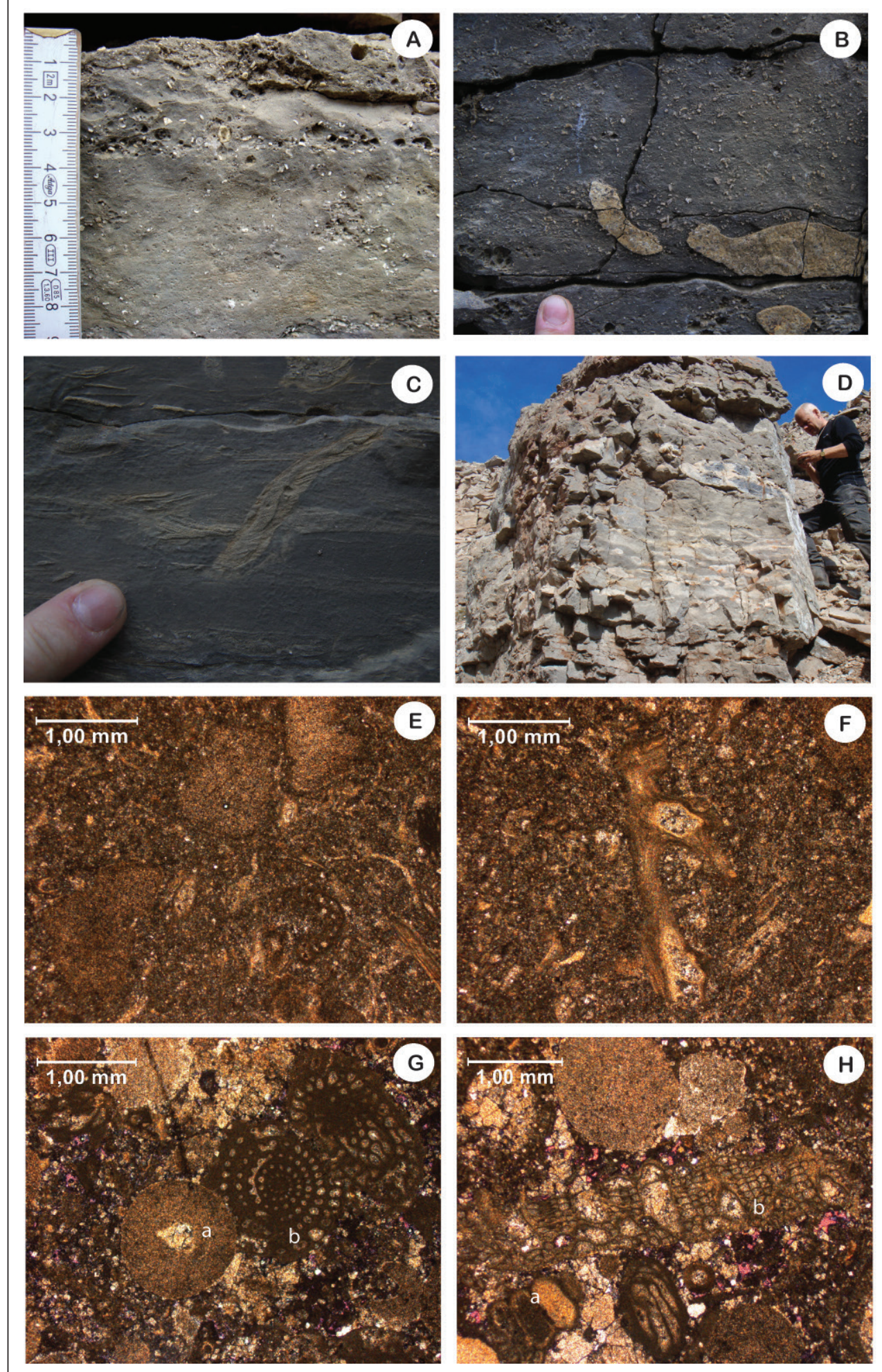

Figure 19. (A) Bryozoan-crinoid wackestones, Finlayfjellet Beds, Asvindalen. (B) Cherty bryozoan-crinoid wackestone highly bioturbated by Thalassinoides, Zoophycos and others. (C) Trace of Zoophycos burrow in muddy carbonate wackestone. (D) Biomottled bryozoan-crinoid wackestones dominated by Thalassinoides burrows. (E) Thin-section of bryozoan-crinoid wackestone to packstone dominated by crinoids, bryozoans, brachiopods and tetrataxid foraminiferas. (F) Fenestrate bryozoan fragments of the facies. (G) Bryozoan-crinoid packstone dominated by crinoids (a), bryozoans and fusulinids (b). (H) Bryozoan-crinoid packstone dominated by crinoids, foraminiferas (a) and fistulipora bryozoans (b). 
sharp lower boundary, whereas the upper boundary is more gradual towards a more muddy facies.

In thin-section, the texture ranges from poorly to moderately sorted, bioclastic wackestones to packstones dominated by fenestrate and trepostome bryozoans, crinoids and small brachiopods. Additional biogenic components are fusulinids, rugose corals, forminiferas, trilobites, Tubiphytes, phylloid algae and sponge spicules. Encrusting foraminiferas and beresellids are absent in this facies.

Occurrence: The bryozoan-crinoid wackestones to packstones are widespread in the Wordiekammen succession being very abundant in the distally located sections of the Kapitol Member where they form 0.5-5 m-thick intervals that can be correlated between Trollfuglfjella, Gangerrolvfjella and Rinddalen. The bryozoan-crinoid facies is also very common in the Tyrrellfjellet sequence 2 where it forms the main facies. The bryozoan-crinoid facies commonly occurs in the basal part of the individual depositional cycles immediately above Micrcodium-overprinted surfaces.

Interpretation: The bryozoan-crinoid wackestones to packstones are characterised by the absence of lightdependent organisms and a dominance of a bryonoderm association suggesting deposition in deeper (and colder) marine settings (Lees \& Buller, 1972; Blendinger et al., 1997; Hüneke et al., 2001). Accordingly, this facies is interpreted as having been deposited on the deeper part of the ramp. The presence of sponge spicules suggests a close association with the spiculite mudstone facies. Crinoid-dominated beds are interpreted as tempestites by many and regarded as diagnostic for mid- to outerramp environments (Wilson, 1975; Burchette \& Wright, 1992).

\section{Spiculitic mudstones}

Description: The spiculitic mudstones consist of medium-bedded, grey to dark grey mudstones characterised by pronounced bioturbation of Thalassioniodes and Zoophycos (Fig. 20). The mudstones are interbedded with thinner packstones, 2-30 mm thick. In thin-sections, the texture ranges from poorly to well sorted mudstones with rare sponge spicules and bryozoan to packstone layers with a sharp and irregular base and flat but more delusive top. The packstones consist of normally graded and oriented spicules.

Occurrence: The spiculitic mudstones are common in the lower part of Tyrrellfjellet sequence 2 .

Interpretation: The spiculitic mudstones, like the bryozoan-crinoid wackestones to packstones, are characterised by the absence of light-dependent organisms, and the dominance of spicules indicates a very specialised fauna in a deep and cold environmental setting (Lees \& Buller, 1972; Blendinger et al., 1997). The facies is interpreted as an outer-ramp deposit and represents the deepest setting recognised on the Nordfjorden High.

\section{Facies associations}

Based on the identified sedimentary facies, 10 facies association are recognised in the Wordiekammen Formation on the Nordfjorden High (Fig. 21). Each association represents a predictable pattern of facies, 0.5-22 m thick, which may be repeated many times in the given stratigraphic interval and produce a distinct cyclicity of the sediments. The cycle boundaries are commonly characterised by Microcodium although caliche and karst also are seen. The characteristics of the cycles are given in Table 1; for a more detailed description and discussion, see Ahlborn (2014). The distribution of cycle types within the Wordiekammen succession reflects both the vertical and the lateral facies variation on the carbonate ramp through time. Direct correlation of individual cycles has proven difficult in the Kapitol Member. Here, cycle bundles of several successive and identical cycles are the best correlation tool. However, in the overlying Tyrrellfjellet Member the presence of several isochronous lithological marker beds makes further subdivision possible. Based on this fine-masked resolution, correlation of cycles, even those of only a few metres thickness, is possible creating a firm understanding of the depositional evolution of this part of the formation (Ahlborn, 2014).

\section{Depositional environments}

The recognised facies reflect deposition from peritidal environments to below storm wave base, with a volumetric dominance of deeper subtidal deposits. The succession shows evidence of repeated subaerial exposure over wide areas both along strike and down dip on the High, indicating that maximum water depths were less than 100-150 m during maximum flooding (Stemmerik, 1996; Soreghan \& Giles, 1999). There is no evidence of shallow water reefs, laterally continuous grainstone shoals or other facies belts indicative of a shelf rim association, so the Wordiekammen Formation is interpreted to be deposited on a homoclinal carbonate ramp. This is in accordance with depositional models developed for the time-equivalent carbonates in the offshore Barents Sea areas, elsewhere in Svalbard and in North Greenland.

Fig. 22 is an idealised depositional model of the Nordfjorden High carbonate ramp showing three distinctive subenvironments, inner, mid and outer ramp. Ideal successions, showing the full spectrum of 
Table 1. Facies association and environmental interpretation of the cycle types of the Nordfjorden High.

\begin{tabular}{ll}
\hline Depositional cycle type & Facies association \\
\hline Type-1 cycle Bioclastic wackestone - packstone & Type-1 cycles range from 3 to7 m in thickness. \\
association & They begin with a basal Coral floatstone dominated \\
& by rugose corals and multithecoporids or more \\
& rarely by spiculitic mudstone. The remaining part \\
& of the cycle consists of a bryozoan-crinoid facies \\
& often overlain by fusulinid-crinoid packstones and \\
& wackestones capped by Microcodium.
\end{tabular}

Type-2 cycle Bioclastic wackestone - foraminifera Type-2 cycles are 1.5-4 $\mathrm{m}$ thick and have a basal grainstone association interval of coral floatstones or bryozoan-crinoid facies overlain by fusulinid-crinoid packstones Depositional environment characterised by abundant tempestites dominated by crinoids, brachiopods and rugose corals. This interval is followed by an upper interval of small foraminifera grainstones overprinted by The Type-1 depositional cycle reflects deposition Microcodium at the top.

Type-3 cycle Bioclastic wackestone - calcareous sandstone association

Type-4 cycle Sandstone
The Type- 3 facies association forms 7-11 m cycles characterised by a lower interval of bioturbated bryozoan-crinoid wackestones to packstones with abundant nodular or layered cherts. It is overlain by bioturbated fusulinidcrinoid packstones and is finally shoaling upward into light grey, small foraminifera grainstones and a calcareous sandstone interval often with Microcodium at the top.

Up to $14 \mathrm{~m}$-thick beds of siliciclastic sandstones, carbonate-rich sandstones and conglomeratic sandstones form a characteristic part of the succession. The sandstones are fine-grained, coasening upward and often characterised by a basal, fine-grained, cross-bedded interval, a middle part of fine- to medium-grained sandstone with lowangle to planar cross-bedding and an upper part of medium- to coarse-grained sandstone with horizontal lamination and abundant Microcodium.

Type-5 cycle Bioclastic wackestones - ooilitic grainstone association
The facies association consists of 7-22 m-thick successions of grey to dark grey, poorly sorted, bioclastic wackestone to grainstone overlain by cross-bedded oolitic grainstones.
The bioclastic wackestone- foraminifera grainstone cycles record initial deposition in open marine subtidal environments below storm wave base. The depositional environment was shallowing over time and the upper parts of the cycles were deposited around or slightly above normal wave base.

The Type- 3 facies association represents a gradual upward shoaling of the depositional environment from open marine subtidal to above normal wave base.
The sandstones are interpreted to reflect deposition in shallow- marine, storm- and tidaldominated environments based on the presence of cross-bedding, hummocky cross-stratification, herringbone foresets and double mud drapes.

The cycle records deep shelf deposition followed by rapid shallowing. The abrupt transition to oolitic grainstones reflects agitated waters above normal wave base and suggests rapid shallowing and forcing of the shallow-water deposits on top of the outer-shelf carbonates and eventually subaerial exposure. The oolitic grainstone is accordingly interpreted as FRST.

Type- 6 cycle Foraminifera grainstones laminated/sabkha mudstones association
Cycles vary in thickness from 2 to $7 \mathrm{~m}$ and are characterised by a basal dolomitised foraminifera packstone to grainstone overlain by dolomitised, biomottled, chert-rich wackestones with crinoids as the only preserved fossil. On top of this rests a thin interval (0.5-1 m thick) of oolitic grainstones followed by laminated mudstones, locally with gypsum nodules.

Type-7 cycle Fusulinid-rich wackestone to packstone association
Type- 7 cycles range from 2 to $5 \mathrm{~m}$ in thickness and often begin with a thin, small, foraminifera packstone overlain by fusulinid wackestones. The fusulinid wackestones are often bioturbated and characterised by chert nodules. The uppermost part of the cycle is dominated by Microcodium and overlies a whitish or yellowish dolomite interval.
The Type- 6 cycle reflects deposition in shallowwater to peritidal environments and records the most proximal carbonate environment preserved in the Wordiekammen platform.
The Type-7 cycles record deposition in open marine, subtidal environments below storm wave base. It is closely related to the Paleoaplysina bioherms.
The Type- 8 cycles range from 0.2 to $6 \mathrm{~m}$ in thickness and are composed of a thin basal interval of small foraminifera grainstones overlain by crinoid-dominated wackestones followed by an upward increase in Paleoaplysina plates. The lower interval is overlain by a generally thick Paleoaplysina bindstone interval characterised by a vuggy or brecciated appearance.
The Type- 8 cycle is characterised by a thin wackestone interval interpreted as the pioneering stage which gradually passes into the Paleoaplysina bindstone repre-senting the core and colonial stage of the buildups of the Tyrrellfjellet Member of central Spitsbergen. The cycle resembles the Paleoaplysina bioherm cycles recognised by Skaug et al. (1982). 
Table 1. Continued.

\begin{tabular}{|c|c|c|}
\hline Depositional cycle type & Facies association & Depositional environment \\
\hline Type- 9 cycle Paleoaplysina float-stone association & $\begin{array}{l}\text { Type 9-cycles range from } 1.5 \text { to } 6 \mathrm{~m} \text { in thick- } \\
\text { ness and consist of a lower interval dominated by } \\
\text { muddy Paleoaplysina floatstones overlain by less } \\
\text { muddy Paleoaplysina floatstones with a higher } \\
\text { forminifera and Tubiphytes content }\end{array}$ & $\begin{array}{l}\text { The floatstone-dominated cycle reflects an open } \\
\text { marine, subtidal carbonate deposition at or below } \\
\text { normal wave base. The occurrence of muddy } \\
\text { Paleoaplysina floatstone directly overlying the } \\
\text { previous depositional cycle, and not divided by a } \\
\text { basal interval of Bryozoan-crinoid or Fusulinid- } \\
\text { crinoid wackestone to packstones, suggests } \\
\text { that the onset of deposition at the crest was } \\
\text { subsequent to the initial pioneering stage of the } \\
\text { bioherms. }\end{array}$ \\
\hline $\begin{array}{l}\text { Type-10 cycle Fusulinid-crinoid wackestone to } \\
\text { packstone - Paleoaplysina floatstone association }\end{array}$ & $\begin{array}{l}\text { This group of associated facies forms } 2.5-6 \\
\text { m-thick depositional cycles characterised by a } \\
\text { lower fusulinid-crinoid packstone followed by } \\
\text { fusulinid-crinoid wackestones and overlain by } \\
\text { Paleoaplysina floatstones characterised by a low } \\
\text { foraminifera content. The upper part consists of } \\
\text { Paleoaplysina floatstones with numerous fora- } \\
\text { miniferas and Tubiphytes, capped by a subaerial } \\
\text { exposure surface with Microcodium. }\end{array}$ & $\begin{array}{l}\text { The cycle represents open marine, subtidal } \\
\text { carbonate deposition at or below normal wave } \\
\text { base. The Paleoaplysina floatstone indicates } \\
\text { the proximity of Paleoaplysina buildups but } \\
\text { likely represents the most deep-water bioherm } \\
\text { association yet recognised. }\end{array}$ \\
\hline
\end{tabular}

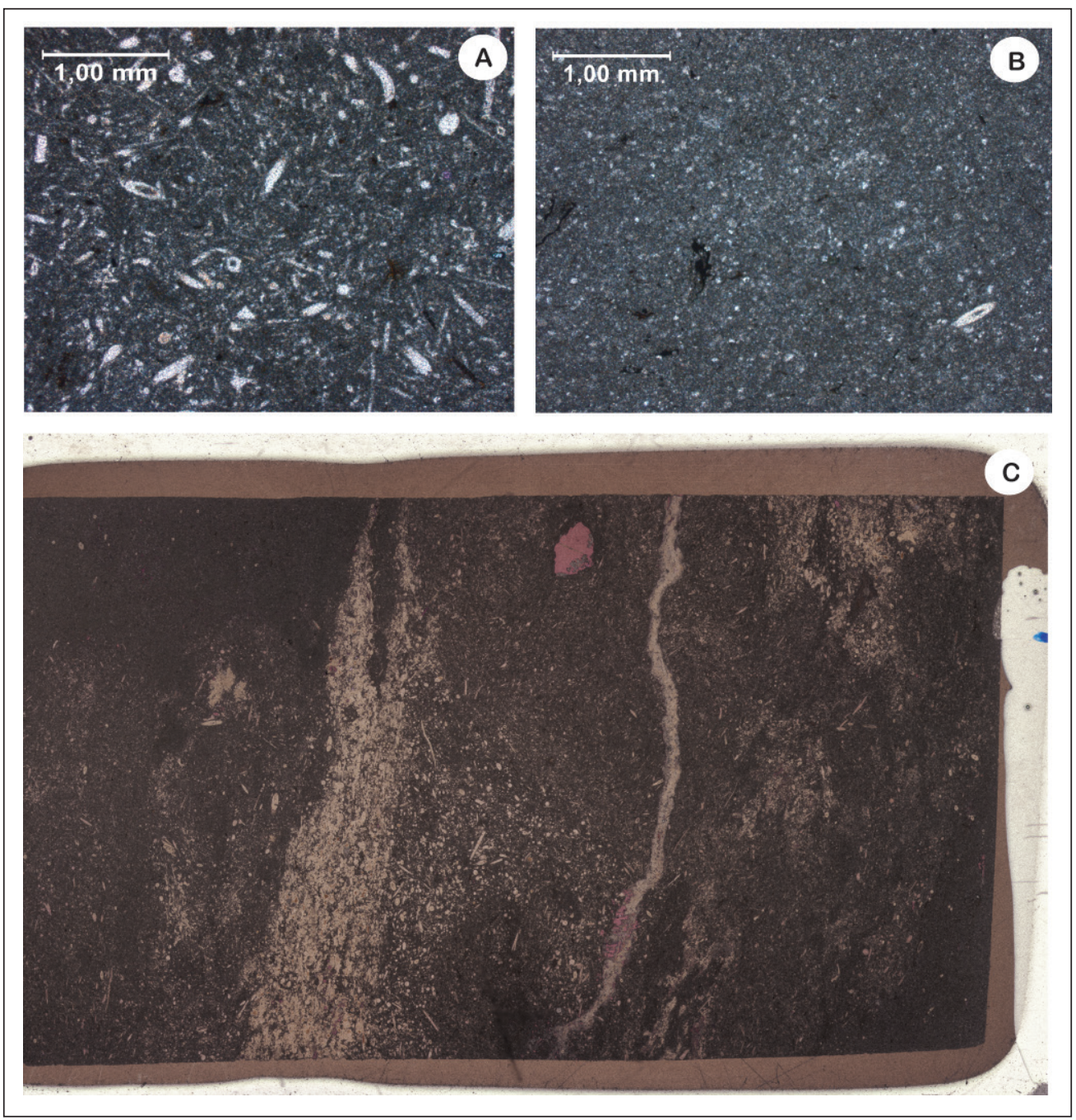

Figure 20. (A) Thin-section of spiculite wackestone dominated by sponge spicules. (B) Spiculite mudstone with rare sponge spicules. Brown patches represent small pockets of residual bituminous material. (C) Full thin-section of a spiculite facies containing a tempestite layer composed of denser deposited spicules (top right). The lower boundary of the tempestite is irregular and sharply overlain by coarser spiculite bioclasts. Upwards the density of bioclasts decreases. Smaller pockets of concentrated bioclasts may represent burrows due to bioturbation. 


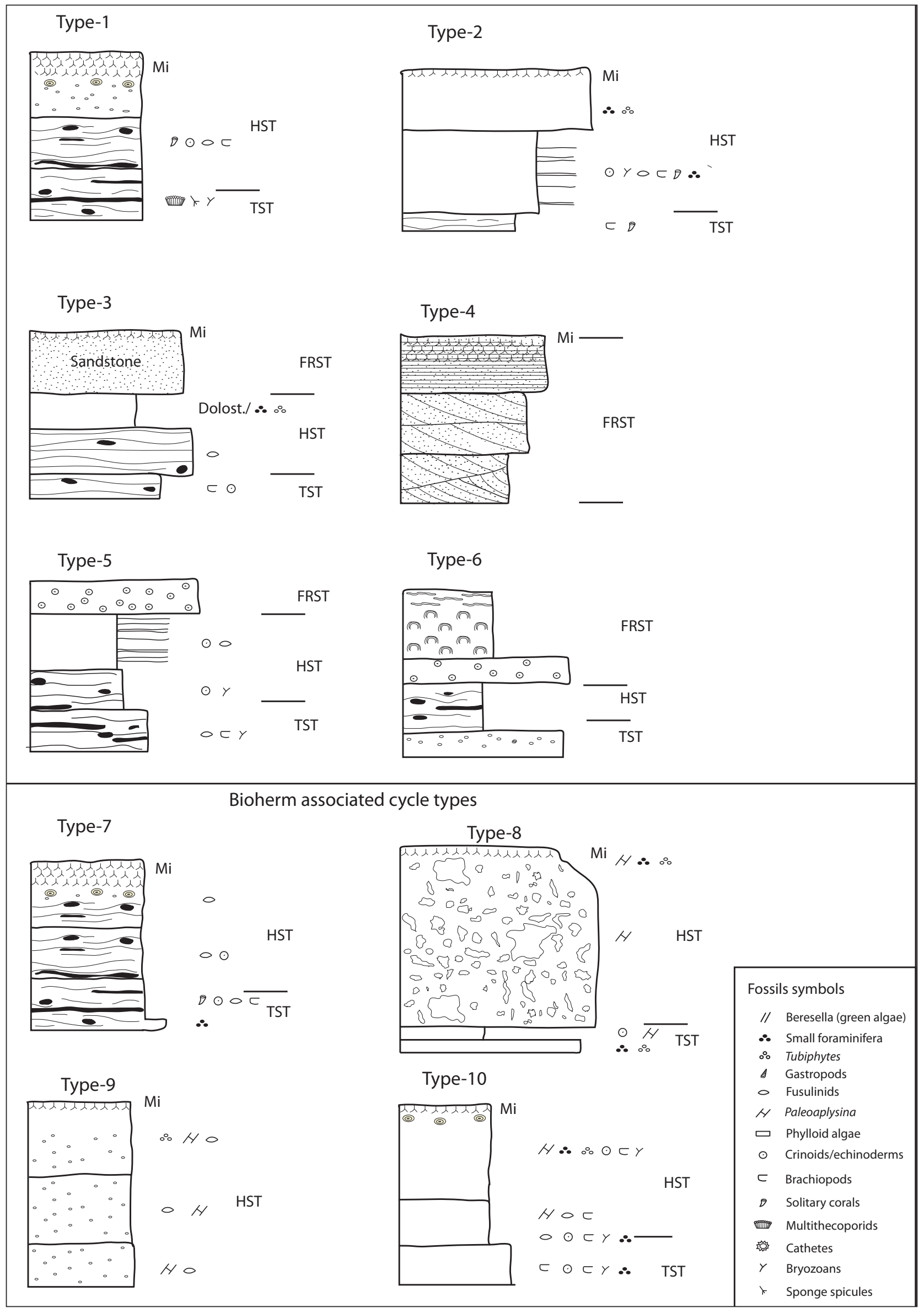

Figure 21. The interpreted depositional cycles of the Wordiekammen Formation. Abbreviations: TST - Transgressive Systems Tract, HST - Highstand Systems Tract, FRST - Forced Regressive Systems Tract, Mi - Microcodium horizon. 


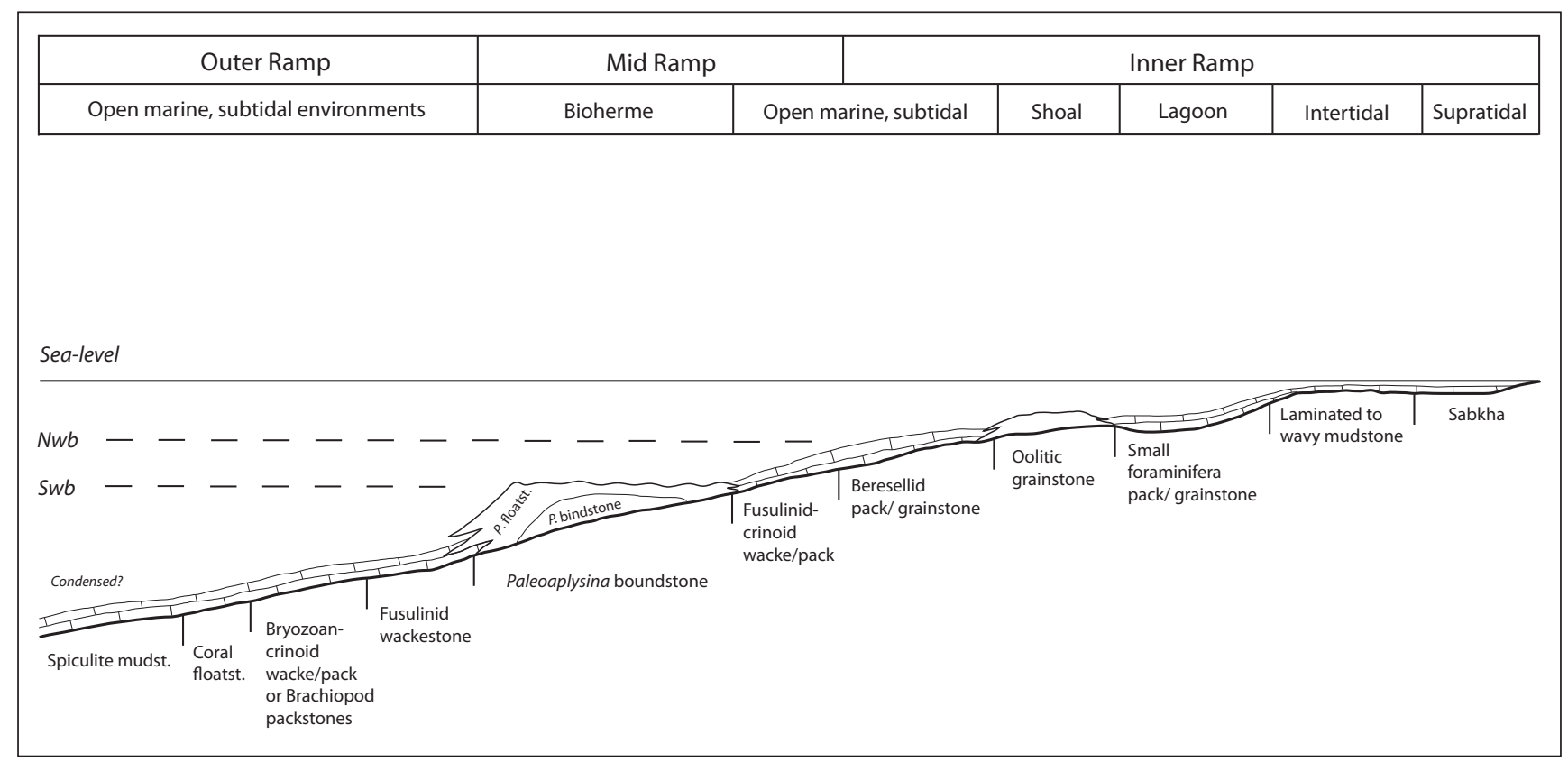

Figure 22. Idealised geological model of the carbonate ramp of the Nordfjorden High The oolitic facies and beresellid grainstone facies are included although they are rare in the studied succession. Abbreviations: Nwb - normal wave base, Swb - storm wave base.

environments are rare; peritidal and oolitic grainstone facies are rare and in most areas the inner-ramp succession is not preserved and the majority of the succession consists of middle- and outer-ramp facies with repeated evidence of subaerial exposure.

The inner ramp is characterised by peritidal, laminated mudstones and rare nodular gypsum and lagoonal, shoal and shallow-marine wackestones to grainstones. They are dominated by small foraminifera and calcareous algae and encrustation and micritisation of grains are often pervasive, all typical for Late Palaeozoic, shallow-marine, warm-water environments (Beauchamp, 1994). The more grainy, bereselid and foraminifera-dominated facies indicate deposition above normal wave base. The mid ramp, defined as the area from normal wave base to storm wave base, is characterised by common tempestite beds (Burchette \& Wright, 1992). The up-dip transition is placed between the beresellid packstones to grainstones and the fusulinidcrinoid wackestones to packstones, which is believed to reflect decreasing agitation of the depositional environment. The mid ramp represents a mixed photozoan and heterozoan association and holds the most diverse biological communities. The outer ramp is dominated by more muddy facies characterised by different types of bryozoans, crinoids, brachiopods and sponges. These communities represent the heterozoan associations (James, 1997) and thus reflect deeper and cooler depositional conditions (Lees \& Buller, 1972; Lees, 1975). This environment was less affected by storms and heavily influenced by bioturbation by Thalassinoides and Zoophycos.

Unfortunately the studied outcrops were not suited for panoramas to illustrate the large-scale geometries and are thus not provided in the paper.

\section{Evolution of the Nordfiorden carbonate platform}

The Wordiekammen Formation consists of four, loworder, depositional sequences on the Nordfjorden High. The sequences are dated as Late Moscovian, Kasimovian to Early Gzhelian, Early Gzhelian to Late Asselian and Early Sakmarian in age, and represent time spans from less than 3 to approximately 8 Myr (Nilsson, 1993; Schmitz \& Davydov, 2012). The sequences are defined on the basis of long-distance correlation of key lithological marker beds and the stacking patterns of the depositional cycles. They reflect the depositional response of the carbonate ramp to longer-term changes in eustatic sea-level and climate punctuated by higher frequency, glacioeustatic, sea-level fluctuations. The effects of tectonics are minor and mainly seen as differential subsidence across the older Carboniferous faults.

\section{Kapitol sequence 1}

The Kapitol sequence 1 represents deposition during the initial flooding of the Nordfjorden High. The lower boundary is an unconformity as the sequence rests directly on Devonian sedimentary rocks. The upper boundary is a well-defined karst surface at most localities along Billefjorden, while a less prominent karst surface is recognised at the top farther to the west. The Kapitol sequence 1 is wedge-shaped, 12-36 m thick, being thickest in the distal localities towards the west and thinnest in the crestal areas towards the east. The Yggdrasilkampen localities near the Billefjorden Fault Zone provide an exception to this overall pattern (Fig. 5B). The Kapitol sequence 1 predates sediments 
belonging to the Early Kasimovian Protriticites pseudomontiparus - Obsoletes obsoletes fusulinid zone A of Nilsson (1993). It is dated at Skansen where it contains fusulinids of Late Moscovian age approximately $12 \mathrm{~m}$ above the base (data in Pickard et al., 1996).

The sequence consists of up to 10 exposure-capped cycles in the distal areas. The transgressive part of the Kapitol sequence 1 is composed of cycles with interbedded sandstone and thin carbonate wackestones to packstones characterised by caliche or Microcodium overprint. They are thickening upwards towards a thick, bioturbated, chert-dominated type-1 cycle which is believed to represent $3^{\text {rd }}$-order maximum flooding (MFS) in these areas (Fig. 5A). The siliciclastics were most likely sourced from the crestal areas of the High which were not drowned until the time of $3^{\text {rd }}$-order maximum flooding. The highstand systems tract (HST) is carbonate dominated and mainly composed of Microcodium-capped type-2 cycles which become thinner towards the top of the sequence. The upper sequence boundary is a well developed karst surface in most areas and the upper part of the sequence is severely overprinted, particularly in the crestal areas along Billefjorden (see Figs. 5A, B, 7).

The shape and internal architecture of the sequence implies that deposition occurred mainly in the distal, down-dip areas during the initial transgression so that the transgressive systems tract (TST) thins from $15 \mathrm{~m}$ at Trollfuglfjella to less than $1 \mathrm{~m}$ at Skansen (Fig. 5A). In contrast, the HST is relatively uniform in thickness and facies across the ramp suggesting very little relief. A notable exception to this pattern is the Yggdrasillkampen $\mathrm{N}$ locality where thick transgressive deposits occur. This may reflect continuous movements along the Billefjorden Fault Zone during deposition.

The depositional cycles in the TST are mainly capped by caliche and the entire sequence is karst overprinted suggesting deposition during a period with a relatively humid climate compared to the underlying evaporitic Minkinfjellet Formation and the overlying parts of the Wordiekammen Formation which are characterised by Microcodium-capped cycles and the rare presence of gypsum (Esteban \& Klappa, 1983; Wright, 1994).

\section{Kapitol sequence 2}

The Kapitol sequence 2 rests on the top of the Kapitol 1 sequence boundary across the entire study area. The upper boundary is an erosional surface at the base of a sandstone interval along Billefjorden, whereas massive and thick Microcodium-overprinted units or thin siliciclastic intervals define the top farther to the west. The Kapitol sequence is wedge-shaped, 10-45 $\mathrm{m}$ thick, being thickest in the distal areas towards the west and thinner in the crestal areas towards the east. The Yggdrasilkampen localities in proximity to the
Billefjorden Fault Zone differ from the remaining crestal localities in this overall pattern.

The Kapitol sequence 2 spans the Early Kasimovian to Early Gzhelian based on the presence of fusulinid zones $\mathrm{A}-\mathrm{C}$ in the Skansen section and fusulinid zones A-D in the Trollfuglfjella section (Nilsson, 1993). It is composed of up to 11 exposure-capped cycles in the distal areas. The transgressive part of Kapitol sequence 2 consists of bioturbated and chert-dominated Type- 1 cycles that gradually become thicker toward the $3^{\text {rd }}$ -order maximum flooding surface interpreted to be in the thickest part of the Type-1 cycle bundle (Fig. 5A, B). The overlying HST consists of Type- 1 and Type- 2 cycles and is composed mainly of gradually thinner Type- 2 cycles in the upper part of the sequence. The upper sequence boundary is a conformable to irregular contact between a Microcodium-capped Type-2 cycle and an overlying sandstone interval along the Billefjorden localities. This contact defines a hiatus at the crest and three fusulinid zones (D,E and F) are missing between the top of the Kapitol sequence 2 and the basal limestone in the overlying Tyrellfejellet sequence 1 (Nilsson, 1993). In the distal area towards the west, the upper sequence boundary is defined as a massive, up to 2 m-thick, Microcodium-overprinted unit, or the contact between a Type-2 cycle and an overlying siliciclastic interval. No fusulinid zones are missing at the boundary in these areas. The architecture of the sequence indicates that deposition and carbonate accumulation occurred mainlyon the down-dip part of the ramp. The crest was only periodically flooded at the site of deposition and mainly during the $3^{\text {rd }}$-order highstand since the HST part of the succession is the thickest.

The Yggdrasilkampen localities are characterised by a thicker Kapitol sequence 2 than the other Billefjorden localities mainly due to increased thickness of the TST. This may reflect continued fault movements of the Billefjorden Fault Zone during the Early Kasimovian. The transgressive facies at Yggdrasilkampen shares many similarities to the Black Crag facies in the Billefjorden Trough (Pickard et al., 1996; Samuelsberg \& Pickard, 1999; Aase, 2006) suggesting that this facies type also formed locally on the Nordfjorden High (see Figs. 4E, F, 5A, B). Also the Rinddalen locality, more down-dip on the High, shows increased thicknesses compared to the general pattern which may imply that minor movements and adjustments along faults continued into the Kasimovian.

\section{Tyrrellfjellet sequence 1}

The Tyrrellfjellet sequence 1 rests disconformably on the Kapitol sequence 2 and in many areas is characterised by a transgressive sandstone at the base. The upper boundary is a karst surface in the up-dip areas and is defined as a Microcodium horizon in the distal areas. The Tyrrellfjellet sequence 1 consists of up to 24 exposure- 
capped cycles overprinted by Microcodium. It is relatively uniform in thickness across the study area, 75-84 m, being thickest in the distal localities towards the west and thinnest in the crestal areas along Billefjorden.

The sequence is of Early Gzhelian to Late Asselian age (fusulinid zones D-J) at Trollfuglfjella. Fusulinid zones D-F are missing in the crestal areas, where the sequence spans the Late Ghzelian to Late Asselian (fusulinid zones G-J) (Nilsson, 1993).

A succession of Type- 2 cycles confined to the distal part of the ramp correlates to the interval of non-deposition at the crest and is interpreted to represent a $3^{\text {rd }}$-order LST. The overlying succession backsteps across the sequence boundary and the crestal areas were not flooded until the Late Gzhelian (see Ahlborn, 2014). Sea level continued to rise until Mid Asselian Schwagerina sphaerica fusulinid zone I time. The lower part of the TST is composed of a suite of cycles which are arranged in a predictable pattern with Type- 1 and Type-7 cycles in the distal and down-dip areas and Type-7 to Type-10 and Type- 2 cycles at the crest (Fig. 5C, D). The TST includes three, laterally widespread, Paleoaplysina bioherms (Type- 8 to Type-10 cycles) (Skaug et al., 1982). The cycle pattern gradually back-stepped across the High until Type- 1 cycles dominated across the entire Nordfjorden High in Mid and Late Asselian times.

The $3^{\text {rd }}$-order maximum flooding is recognised as a thick, bioturbated, cherty Type-1 cycle on the crest and an identical but highly condensed facies distally. The lower part of the HST is composed of thick, bioturbated, Type-1 cycles followed by thinner Type- 1 and Type- 8 cycles interbedded with sandstones. This upper part is interpreted as a composite HST-FRST. The sudden arrival of siliciclastic sand is a puzzle since carbonate platform deposits are reported to cover the entire Norwegian Barents Shelf during this time interval (Larssen et al., 2005). We propose that the sand was sourced from aeolian dunes located in eastern Spitsbergen which became flooded during the highest $3^{\text {rd }}$-order sea level and moved basinward during higherorder sea-level falls. In this sense they represent a higherorder FRST. The uppermost forced regressive interval seems to downstep and is capped by a well-developed karst surface in the up-dip areas.

The shape and internal architecture of the sequence indicates that the focus of sediment accumulation shifted from the distal part of the ramp during lowstand and early transgression, to the crestal areas during maximum flooding and early highstand.

\section{Tyrrellfjellet sequence 2 - Finlayfjellet Beds}

The Tyrrellfjellet sequence 2 corresponds to the Finlayfjellet Beds and is believed to reflect deposition following a major rise in sea level during the Early
Sakmarian (Ehrenberg et al., 1998; Larssen et al., 2005; Stemmerik, 2008). The lower boundary is a karstic surface towards the east while juxtaposition of facies associations defines the boundary towards the west. The upper boundary is poorly exposed on the Nordfjorden High. The Tyrrellfjellet sequence 2 differs from the underlying sequences by being relatively uniform in thickness, 43-45 m, across the entire ramp, and by being composed of much thicker cycles. The sequence is of Early Sakmarian age based on recognition of the Eoparafusulina paralinearis fusulinid zone at Kolloseum to the west of the Trollfuglfjella section (Nilsson \& Davydov, 1997).

The Tyrrellfjellet sequence 2 consists of 4-5 cycles defined due to juxtaposition of facies. In contrast to the underlying part of the Wordiekammen Formation, evidence of subaerial exposure is rare. The transgressive part of the sequence is a single Type- 5 cycle, up to $22 \mathrm{~m}$ thick. It is dominated by bioturbated, cherty bryonoderm carbonates composed of bryozoan-crinoid wackestones, brachiopod packstones and spiculite mudstones. The HST consists mainly of Type- 3 and Type- 5 cycles capped by oolitic grainstones or siliciclastics which tend to become thinner upwards. The upper boundary is poorly exposed on the Nordfjorden High but is well exposed at Boltonbreen in the Ny Friesland High and is here defined by a subaerial exposure surface with microkarstic relief (Stemmerik \& Worsley, 2005).

\section{Cyclicity and periodicity}

The cyclic pattern recognised in the Wordiekammen Formation resembles that reported from coeval marine successions elsewhere (Ross \& Ross, 1985; Stemmerik \& Worsley, 1989; Heckel, 1990; Beauchamp, 1994; Ludvig, 1994; Morin et al., 1994; Bugge et al., 1995; Stemmerik et al., 1995; Ehrenberg et al., 1998; Soreghan \& Giles, 1999; Embry \& Beauchamp, 2008; Stemmerik, 2008; Corrochano et al., 2012; Hill et al., 2012; Laya \& Tucker, 2012). It is widely accepted to reflect the depositional response to glacioeustatic sea-level fluctuations linked to the Late Palaeozoic glaciation in southern Gondwanaland (Ross \& Ross, 1985; Veevers \& Powell, 1987; Crowley \& Baum, 1991; Soreghan \& Giles, 1999). At the Nordfjorden High, allocyclic control on deposition is particularly evident in Kapitol sequences 1 and 2 and Tyrrellfjellet sequence 1 where numerous incomplete cycles' are present (Schlager, 2005). Type-1, Type-7 and Type-10 cycles all have facies arrangements indicating very rapid sea-level falls, preserving evidence of subaerial exposure (Microcodium) directly on deeper subtidal facies without evidence of a progradational peritidal succession (Fig. 21). In contrast, the cyclicity in Tyrrellfjellet sequence 2 is less prominent and most cycles lack evidence of subaerial exposure.

The duration of the classical midcontinent cyclotherms is estimated to approximately $400 \mathrm{kyr}$ (Heckel, 1986), 
and it appears that the $400 \mathrm{kyr}$ signal dominates in the Late Carboniferous - Early Permian, tropically located, platform succession (see Schmitz \& Davydov, 2012). In contrast, a dominance of cyclicity controlled by the $100 \mathrm{kyr}$ signal was reported in the Moscovian northern hemisphere subtropical succession in North Greenland (Stemmerik, 1996). The Wordiekammen Formation consists of up to 50 depositional cycles, 21 in the Kapitol Member and 29 in the Tyrrellfjellet Member. However, no single section includes all cycles and the frequent occurrence of karst surfaces over the crest indicates a high potential of missing cycles particularly around sequence boundaries. The investigated section spans approximately 17-18 Myr so simple calculations imply an average duration of 350-360 kyr per cycle. In the best dated part of the succession, Tyrrellfjellet sequence 1, the average duration is even less, approximately $300 \mathrm{kyr}$, suggesting that the observed cyclicity reflects a mixed $100 \mathrm{kyr}$ and $400 \mathrm{kyr}$ signal.

\section{Correlation to the Ny Friesland High}

The time-equivalent succession on the Ny Friesland High to the east of the Billefjorden Fault Zone has been subdivided into four transgressive-regressive sequences based on studies in Bünsow Land (Pickard et al., 1996; Samuelsberg \& Pickard, 1999; Samuelsberg et al., 2000). The boundary between sequences 2 and 3 in Bünsow Land is located at the base of the Gerritbreen Beds (Pickard et al., 1996). It is an erosional surface overlain by a transgressive sandstone and has many characteristics in common with the sequence boundary between the Kapitol sequence 2 and the Tyrrellfjellet sequence 1 . This correlation was also proposed by Pickard et al. (1996). It has been further substantiated by the documentation of Black Crag facies in Kapitol sequence 2 locally on the Nordfjorden High.

The overlying LST of Tyrrellfjellet sequence 1 shows many similarities with the Mathewbreen Beds in Bünsow Land (cf., Pickard et al., 1996) and the three mid-upper Asselian sandstones in the HST of Tyrrellfjellet sequence 1 can be correlated to time-equivalent sandstones in the regressive part of Sequence 3 in Bünsow Land (see Samuelsberg \& Pickard, 1999).

The sequence boundary between Tyrrellfjellet sequences 1 and 2 is recognised as a juxtaposition of LST sabkha and intertidal sediments of Tyrrellfjellet sequence 2 on top a Microcodium horizon in the distal part of the Nordfjorden ramp and as a karst surface over the proximal areas. Similarly, the boundary between transgressive-regressive sequences 3 and 4 in Bünsow Land is defined as juxtaposition of top sabkha facies on top carbonates and siliciclastics (cf., Samuelsberg \& Pickard, 1999, Transgressive Model C). The overlying Tyrrellfjellet sequence 2 corresponds to the Finlayfjellet Beds and is recognised across the entire central
Spitsbergen as a major flooding event where deep subtidal facies are juxtaposed on top peritidal carbonates or karstified sediments. The Finlayfjellet Beds (Tyrrellfjellet sequence 2 and transgressive-regressive sequence 4) lack evidence of subaerial exposure at cycle boundaries both on the Nordfjorden High and in Bünsow Land, suggesting that the shift in depositional style across the sequence boundary was of a regional nature.

\section{Summary and conclusions}

The Wordiekammen Formation at the Nordfjorden High, Central Spitsbergen, is a warm-water, carbonatedominated unit deposited on a westward sloping ramp. It includes 11 sedimentary facies reflecting deposition in peritidal to deep subtidal environments, and three types of diagenetic overprint related to subaerial exposure. The facies were grouped into 10 facies associations, each with a predictable facies stacking pattern (0.5-22 m thick), which may be repeated many times to produce a distinct cyclicity. The cycle boundaries are commonly characterised by the presence of Microcodium and more rarely by caliche and karst.

The succession is divided into four sequences. The Kapitol sequences 1 and 2 are wedge-shaped, being thickest in the distal area towards the west and thinner in the crestal area towards the east, whereas Tyrrellfjellet sequences 1 and 2 have a more uniform thickness across the ramp.

The Wordiekammen succession is composed of 50 depositional cycles, 21 cycles in the Kapitol Member and 29 cycles in the Tyrrellfjellet Member. The cyclicity appears to be controlled by a combined $100 \mathrm{kyr}$ and $400 \mathrm{kyr}$ signal. Our data do not allow us to differentiate between the two signals.

The absence of exposure-capped cycles in Tyrrellfjellet sequence 2 is interpreted to reflect the breakdown of ice-house conditions and waning of ice sheets on Gondwanaland resulting in a change from allocyclic control in the three lower sequences to autocyclic control in the upper, Tyrrellfjellet sequence 2 .

Correlation across the Billefjorden Fault Zone to the time-equivalent succession at Bünsow Land is facilitated by the presence of regionally correlateable erosion surfaces and sandstone units. The succession deposited on the distal part of the Nordfjorden High is showing the same overall depositional evolution as the time-equivalent succession in the Billefjorden Trough, suggesting that they formed part of a connected deeper water ramp environment. The succession deposited over the crestal part of the Nordfjorden High shows evidence of more frequent subaerial exposure and formed a positive feature that divided the two carbonate platforms during sea-level lowstands. 
Acknowledgements. DONG Energy is thanked for funding of the project and permission to publish. We are grateful for the help and company of Snorre Olaussen, Marie Hornum and Thomas Guldborg Petersen during the two fieldwork summers in Spitsbergen. Furthermore, Rikke Bruhn is thanked for the constructive comments and corrections to the manuscript and, finally, based on the corrections and suggestions of NJG reviewers Maria Mutti and Alenka E. Crne, the manuscript was significantly improved.

\section{Reference list}

Aase, M. 2006: Sedimentology and sequence stratigraphy of the Black Crag Beds (Upper Carboniferous), central Spitsbergen. MSc thesis, University of Bergen, $230 \mathrm{pp}$.

Ahlborn, M. 2014: Carboniferous-Permian sedimentology and stratigraphy of the Nordfjorden High and Loppa spur, Arctic Norway. PhD thesis, University of Copenhagen, $127 \mathrm{pp}$.

Beauchamp, B. 1994: Permian climatic cooling in the Canadian Arctic. Geological Society of America Special Paper 288, 229-246.

Blendinger, W., Bowlin, B., Zijp, F.R., Darke, G. \& Ekroll, M. 1997: Carbonate buildup flank deposits: An example from the Permian (Barents Sea, northern Norway) challenges classical facies models. Sedimentary Geology 112, 89-103. doi: 10.1016/S0037-0738(97)00025-0.

Blomeier, D., Scheibner, C. \& Forke, H. 2008: Facies arrangement and cyclostratigraphic architecture of a shallow-marine, warm-water carbonate platform: the Late Carboniferous Ny Friesland Platform in eastern Spitsbergen (Pyefjellet Beds, Wordiekammen Formation, Gipsdalen Group). Facies 55, 291-324. doi: 10.1007/s10347-008-0163-3.

Blomeier, D., Dustira, A., Forke, H. \& Scheibner, C. 2011: Environmental change in the Early Permian of NE Svalbard: from a warm-water carbonate platform (Gipshuken Formation) to a temperate, mixed siliciclastic-carbonate ramp (Kapp Starostin Formation). Facies 57, 493-523. doi: 10.1007/s10347-010-0243-Z

Bugge, T., Mangerud, G., Elvebakk, G., Mørk, A., Nilsson, I., Fanavoll, S. \& Vigran, J.O. 1995: The Upper Paleozoic Succession on the Finnmark Platform, Barents Sea. Norsk Geologisk Tidsskrift 75, 3-30.

Burchette, T.P. \& Wright, V.P. 1992: Carbonate ramp depositional systems. Sedimentary Geology 79, 3-57.

Choquette, P.W. \& Pray, L.C. 1971: Geological nomenclature and Classification of Porosity in Sedimentary Carbonates. American Association of Petroleum Geologists Bulletin 54, 207-250.

Corrochano, D., Barba, P. \& Colmenero, J.R. 2012: Glacioeustatic cyclicity of a Pennsylvanian carbonate platform in a foreland basin setting: An example from the Bachende Formation of the Cantabrian Zone (NW Spain). Sedimentary Geology 245-246, 76-93. doi: 10.1016/j.sedgeo.2011.12.009.

Crowley, T.J. \& Baum, S.K. 1991: Estimating Carboniferous sea-level fluctuations from Gondwanan ice extent. Geology 19, 975-977.

Cutbill, J.L. \& Challinor, A. 1965: Revision of the stratigraphical scheme for the Carboniferous and Permian rocks of Spitsbergen and Bjørnøya. Geological Magazine 102, 418-439.

Dallmann, W.K. 1993: Notes on the stratigraphy, extent and tectonic implications of the Minkinfjellet Basin, Middle Carboniferious of central Spitsbergen. Polar Research 12, 153-160.

Dallmann, W.K., Gjelberg, J., Harland, W.B., Johannesen, E.P., Keilen, H.B., Larssen, G.B., Lønøy, A., Midboe, P.S., Mørk, A., Nagy, J., Nilsson, I., Nøttvedt, A., Olaussen, S., Steel, R.J. \& Worsley, D. 1999: Lithostratigraphic Lexicon of Svalbard - Upper Palaeozoic to Quaternary bedrock. In Dallmann, W.K. (ed.): Norsk Polarinstitut, pp. $1-322$.

Davydov, V.I. \& Nilsson, I. 1998: Fusulinid succession from the Middle-Upper Carboniferous Boundary beds on Spitsbergen, Actic Norway. Paleontological Society 1, 1-45.

Dons, C.E. 1983: Facies og paleostrømanalyse av Nordenskiöldbreen formasjonen (overkarbon-underperm), sentrale Spitsbergen. Cand. Scient. thesis, University of Oslo, 344 pp.
Dunham, R.J. 1962: Classification of Carbonate Rocks According to Depositional Textures. In Ham, W.E. (ed.): M1: Classification of Carbonate Rocks - A Symposium, American Association of Petroleum Geologists Special Volumes, pp. 108-121.

Ehrenberg, S.N., Nielsen, E.B., Svånå, T.A. \& Stemmerik, L. 1998: Depositional evolution of the Finnmark carbonate platform, Barents Sea: results from wells 7128/6-1 and 7128/4-1. Norsk Geologisk Tidsskrift $78,318-318$.

Eliassen, A. \& Talbot, M.R. 2003: Sedimentary facies and depositional history of the mid-Carboniferous Minkinfjellet Formation, Central Spitsbergen, Svalbard. Norwegian Journal of Geology 83, 299-318.

Embry, A. \& Beauchamp, B. 2008: Chapter 13 Sverdrup Basin. Sedimentary Basins of the World 5, 451-471. doi: 10.1016/s18745997(08)00013-0.

Esteban, M. \& Klappa, C.F. 1983: Subaerial exposure environment. In Scholle, P.A., Bebout, D.G. \& Moore, C.H. (eds.): Carbonate Depositional Environments, Memoir 33, American Association of Petroleum Geologists, Tulsa, OK1-54.

Flügel, E. 2004: Microfacies of Carbonate Rocks - Analysis Interpretation and Application, 2nd Edition. Springer, $913 \mathrm{pp}$.

Gabrielsen, R.H., Færseth, R.B., Jensen, L.N., Kalheim, J.E. \& Riis, F. 1990: Structural elements of the Norwegian continental shelf - Part 1: The Barents Sea Region. Norwegian Petroleum Directorate Bulletin 2, 1-47.

Gernigon, L. \& Brönner, M. 2012: Late Palaeozoic architecture and evolution of the southwestern Barents Sea: insights from a new generation of aeromagnetic data. Journal of the Geological Society 169, 449-459. doi: 10.1144/0016-76492011-131.

Gudlaugsson, S.T., Faleide, J.I., Johansen, S.E. \& Breivik, A.J. 1998: Late Palaeozoic structural development of the South-western Barents Sea. Marine and Petroleum Geology 15, 73-102.

Hanken, N.M. \& Nielsen, J.K. 2013: Upper Carboniferous-Lower Permian Paleoaplysina build-ups on Svalbard: the influence of climate, salinity and sea-level. In Gasiewicz, A. \& Slowakiewicz, M. (eds.): Palaeozoic Climate Cycles: Their Evolutionary and sedimentological impact, Geological Society of London Special Publications 376. doi: $10.1144 /$ SP376.17.

Harland, W.B. \& Geddes, I. 1997: Chapter 17 Carboniferous-Permian history of Svalbard. Geological Society of London Memoirs 17, 310339. doi: 10.1144/gsl.mem.1997.017.01.17.

Heckel, P.H. 1986: Sea-level curve for Pennsylvanian eustatic marine transgressive-regressive depositional cycles along midcontinent outcrop belt, North America. Geology 14, 330-334. doi: 10.1130/0091-7613(1986)14<330:scfpem >2.0.co;2.

Heckel, P.H. 1990: Evidence for global (glacial-eustatic) control over upper Carboniferous (Pennsylvanian) cyclothems in midcontinent North America. Geological Society of London Special Publications 55, 35-47. doi: 10.1144/gsl.sp.1990.055.01.02.Hill, J., Wood, R., Curtis, A. \& Tetzlaff, D.M. 2012: Preservation of forcing signals in shallow water carbonate sediments. Sedimentary Geology 275-276, 79-92. doi: 10.1016/j.sedgeo.2012.07.017.Holliday, D.W. \& Cutbill, J.L. 1972: The Ebbadalen Formation (Carboniferous), Spitsbergen. Proceedings of the Yorkshire Geological Society 39, 1-32. doi: 10.1144/pygs.39.1.1.Hüneke, H., Joachimski, M., Buggisch, W. \& Lützner, H. 2001: Marine Carbonate Facies in Response to Climate and Nutrient Level: The Upper Carboniferous and Permian of Central Spitsbergen (Svalbard). Facies 45, 93-136.

James, N.P. 1997: The Cool-water Carbonate Depositional Realm. In James N.P. \& Clarke, J.A.D. (eds.): Cool-water Carbonates, Society for Sedimentary Geology Special Publication 56, pp. 1-22.

Johannesen, E.P. \& Steel, R.J. 1992: Mid-Carboniferous extension and rift-infill sequences in the Billefjorden Trough, Svalbard. Norsk Geologisk Tidsskrift 72, 35-48.

Kabanov, P., Anadón, P. \& Krumbein, W.E. 2008: Microcodium: An extensive review and a proposed non-rhizogenic biologically induced origin for its formation. Sedimentary Geology 205, 79-99. doi: 10.1016/j.sedgeo.2008.02.003.Klappa, C.F. 1978: Biolithogenesis of Microcodium: elucidation. Sedimentology 25, 489-522. 
Kosir, A. 2004: Microcodium Revisited: Root Calcification Products of Terrestrial Plants on Carbonate-rich Substrates. Journal of Sedimentary Research 74, 845-857.

Larssen, G.B., Elvebakk, G., Henriksen, L.B., Kristensen, S.E., Nilsson, I., Samuelsberg, T.J., Svånå, T.A., Stemmerik, L. \& Worsley, D. 2005: Upper Palaeozoic lithostratigraphy of the southern part of the Norwegian Barents Sea. Norges Geologiske Undersøkelse Bulletin 44, $1-43$.

Laya, J.C. \& Tucker, M.E. 2012: Facies analysis and depositional environments of Permian carbonates of the Venezuelan Andes: Palaeogeographic implications for Northern Gondwana. Palaeogeography, Palaeoclimatology, Palaeoecology 331-332, 1-26. doi: 10.1016/j. palaeo.2012.02.011.Lees, A. 1975: Possible Influence of Salinity and Temperature on Modern Shelf Carbonate Sedimentation. Marine Geology 19, 159-198.

Lees, A. \& Buller, A.T. 1972: Modern temperate-water and warm-water shelf carbonate sediments contrasted. Marine Geology 13, M67M73.

Loucks, R.G. 1999: Paleocave Carbonate Reservoirs: Origins, BurialDepth Modifications, Spatial Complexity, and Reservoir Implications. American Association of Petroleum Geologists Bulletin 83, 1795-1834.

Ludvig, A.O. 1994: Cyclic sedimentation and climatically caused sealevel changes in the Late Palaeozoic of Central Europe. Geologische Rundschau 83, 799-810.

Lønøy, A. 1995: A Mid-Carboniferous, carbonate-dominated platform, Central Spitsbergen. Norsk Geologisk Tidsskrift 75, 48-63.

Morin, J., Desrochers, A. \& Beauchamp, B. 1994: Facies Analysis of Lower Permian Platform Carbonates, Sverdrup Basin, Canadian Arctic Archipelago. Facies 31, 105-130.

Nilsson, I. 1993: Upper Paleozoic fusulinid stratigraphy of the Barents Shelf and surrounding areas. $\mathrm{PhD}$ thesis, University of Troms $\varnothing, 538$ pp.Nilsson, I. \& Davydov, V.I. 1997: Fusulinid biostratigraphy in Upper Carboniferous (Gzhelian) and Lower Permian (AsselianSakmarian) successions of Spitsbergen, Arctic Norway. Permophiles 30, 18-24.

Pickard, N.A.H., Eilertsen, F., Hanken, N.M., Johansen, T.A., Lønøy, A., Nakrem, H.A., Nilsson, I., Samuelsberg, T.J. \& Somerville, I.D. 1996: Stratigraphic framework of Upper Carboniferous (MoscovianKasimovian) strata in Bunsow Land, central Spitsbergen: Palaeogeographic implications. Norsk Geologisk Tidsskrift 76, 169-185.

Purdy, E.D. \& Waltham, D. 1999: Reservoir Implications of Modern Karst Topography. American Association of Petroleum Geologists Bulletin 83, 1774-1794.

Ross, C.A. \& Ross, J.R.P. 1985: Late Paleozoic depositional sequences are synchronous and worldwide. Geology 13, 194-197.

Ross, C.A. \& Ross, J.R.P. 1991: Paleozoic Foraminifera. Biosystems 25, 39-51.

Saller, A.H., Dickson, J.A.D. \& Matsuda, F. 1999: Evolution and Distribution of Porosity Associated with Subaerial Exposure in Upper Paleozoic Platform Limestones, West Texas. American Association of Petroleum Geologists Bulletin 83, 1835-1854.

Samuelsberg, T.J. \& Pickard, N.A.H. 1999: Upper Carboniferous to Lower Permian transgressive-regressive sequences of central Spitsbergen, Arctic Norway. Geological Journal 34, 393411. doi: 10.1002/(Sici)1099-1034(199911/12)34:4<393::AidGj831>3.0.Co;2-G.Samuelsberg, T.J., Pickard, N.A.H., Hanken, N.M. \& Lønøy, A. 2000: Late Paleozoic carbonate ramp evolution on central Spitsbergen: a stratigraphic record of glacio-eustasy, autocyclicity and tectonism in a post-rift setting. In 'Late Palaeozoic Carbonates on the Norwegian Barents Shelf', a Dissertation for the degree of Doctor Scientiarum, University of Tromsø, pp. 1-205.

Schlager, W. 2005: Carbonate Sedimentology and Sequence Stratigraphy. Society for Sedimentary Geology, Tulsa, $200 \mathrm{pp}$.

Schmitz, M.D. \& Davydov, V.I. 2012: Quantitative radiometric and biostratigraphic calibration of the Pennsylvanian-Early Permian (Cisuralian) time scale and pan-Euramerican chronostratigraphic correlation. The Geological Society of America Bulletin 124, 549-577.
Shinn, E.A. 1983: Birdseyes, Fenestrae, Shinkage Pores, and Loferites: a Reevaluation 1. Journal of Sedimentary Petrology 53, 0619-0628.

Skaug, M., Dons, C.E., Lauritzen, Ø. \& Worsley, D. 1982: Lower Permian paleoaplysinid bioherm and associated sediments from central Spitsbergen. Polar Research 2, 57-74.

Soreghan, G.S. \& Giles, K.A. 1999: Amplitudes of Late Pennsylvanian glacioeustasy. Geology 27, 255-258. doi: 10.1130/0091-7613(1999)027<0255:aolpg>2.3.co;2.Steel, R.J. \& Worsley, D. 1984: Svalbards's post-Caledonian strata - an atlas of sedimentational patterns and palaeogeographical evolution. In Spencer, A.M. (ed.): Petroleum Geology of the North European Margin, Norwegian Petroleum Society, Graham \& Trotman, London, pp. 109-135.

Stemmerik, L. 1996: High frequency sequence stratigraphy of a siliciclastic influenced carbonate platform, lower Moscovian, Amdrup Land, North Greenland. In Howell, J.A. \& Aitken, J.F. (eds.): High Resolution, Sequence Stratigraphy: Innovations and Applications, Geological Society of London Special Publication 104, pp. 347-365.

Stemmerik, L. 2000: Late Palaeozoic evolution of the North Atlantic margin of Pangea. Palaeogeography, Palaeoclimatology, Palaeoeco$\log y$ 161, 95-126.

Stemmerik, L. 2008: Influence of late Paleozoic Gondwana glaciations on the depositional evolution of the northern Pangean shelf, North Greenland, Svalbard, and the Barents Sea. Geological Society of America Special Papers 441, 205-217. doi: 10.1130/2008.2441(14. Stemmerik, L. \& Worsley, D. 1989: Late Palaeozoic sequence correlations, North Greenland, Svalbard and the Barents Shelf. In Collinson, J.D. (ed.): Correlation in Hydrocarbon Exploration, Norwegian Petroleum Society, Graham \& Trotman, London, pp. 99-111.

Stemmerik, L. \& Worsley, D. 2005: 30 years on - Arctic Upper Palaeozoic stratigraphy, depositional evolution and hydrocarbon prospectivity. Norwegian Journal of Geology 85, 151-168.

Stemmerik, L., Larson, P.A., Larssen, G.B., Mørk, A. \& Simonsen, B.T. 1994: Depositional evolution of Lower Permian Palaeoaplysina build-ups, Kapp Duner Formation, Bjørnøya, Arctic Norway. Sedimentary Geology 92, 161-174.

Stemmerik, L., Nilsson, I. \& Elvebakk, G. 1995: Gzelian-Asselian depositional sequences in the western Barents Sea and North Greenland. Norwegian Petroleum Society Special Publication 5, 529-544.

Stemmerik, L., Elvebakk, G. \& Worsley, D. 1999: Upper Palaeozoic carbonate reservoirs on the Norwegian Arctic Shelf: delineation of reservoir models with application to the Loppa High. Petroleum Geoscience 5, 173-187.

Veevers, J.J. \& Powell, M. 1987: Late Paleozoic glacial episodes in Gondwanaland reflected in transgressive-regressive depositional sequences in Euramerica. Geological Society of America Bulletin 98, 475-487.

Wilson, J.L. 1975: Carbonate Facies in Geological History. Springer, New York, PP.

Worsley, D. 2008: The post-Caledonian development of Svalbard and the western Barents Sea. Polar Research 27, 298-317. doi: 10.1111/j.1751-8369.2008.00085.x.

Worsley, D., Agdestein, T., Gjelberg, J., Kirkemo, K., Mørk, A., Nilsson, I., Olaussen, S., Steel, R.J. \& Stemmerik, L. 2001: The geological evolution of Bjørnøya, Arctic Norway: implications for the Barents Shelf. Norwegian Journal of Geology 81, 195-234.

Wright, V.P. 1994: Paleosols in shallow marine carbonate sequences. Earth-Science Reviews 35, 367-395. 